\title{
Combined use of companion planting and PGPR for the assisted phytoextraction of trace metals $(\mathrm{Zn}, \mathrm{Pb}, \mathrm{Cd})$
}

\author{
Agnieszka Konkolewska ${ }^{1}$ - Aneta Piechalak ${ }^{2}$ - Liliana Ciszewska ${ }^{3} \cdot$ Nina Antos-Krzemińska ${ }^{4}$. Tomasz Skrzypczak ${ }^{5}$. \\ Anetta Hanć ${ }^{6} \cdot$ Krzysztof Sitko $^{7} \cdot$ Eugeniusz Małkowski $^{7} \cdot$ Danuta Barałkiewicz $^{6} \cdot$ Arleta Małecka $^{8}$
}

Received: 22 May 2019 / Accepted: 27 January 2020 /Published online: 8 February 2020

(C) The Author(s) 2020

\begin{abstract}
Biomass production and metal accumulation in plant tissue (bioconcentration) are two critical factors limiting the phytoextraction rate. Metal translocation to aboveground organs should be accounted for as the third most important factor, as harvesting of the plant roots is usually economically disadvantageous. These three parameters could be potentially increased with the use of companion planting, a well-known agricultural technique, and inoculation with plant growth-promoting bacteria (PGPB). The aim of the study was to determine whether intercropping and inoculation with endophytic PGPB (Burkholderia phytofirmans $\mathrm{PsJN}^{\mathrm{T}}$ ) can increase the efficiency of phytoextraction of $\mathrm{Zn}, \mathrm{Pb}$, and $\mathrm{Cd}$. The study was conducted on Brassica juncea (L.) Czern. "Małopolska" grown in a monoculture or co-planted with Zea mays L. "Codimon" and Medicago sativa L. "Sanditi." Results show that companion planting and inoculation with rhizobacteria can increase the efficiency of metal phytoextraction, mainly by increasing the yield of dry biomass and the survival rate of plants grown on contaminated soil. We have shown that the simultaneous planting of $B$. juncea with M. sativa and inoculation with PGPB were the most efficient variants of assisted phytoextraction reaching a recovery of $95 \%$ $\mathrm{Zn}, 90 \% \mathrm{Cd}$, and on average about $160 \% \mathrm{~Pb}$ compared with control B. juncea plants grown in monoculture.
\end{abstract}

Keywords Phytoextraction $\cdot$ Elements $\cdot$ Companion planting $\cdot$ Plant growth-promoting bacteria PGPR

\section{Introduction}

Trace metals (such as $\mathrm{Cd}, \mathrm{Pb}, \mathrm{Cu}$, and $\mathrm{Zn}$ ) present in excess negatively affect plant growth, development, and biomass

Responsible editor: Elena Maestri

Electronic supplementary material The online version of this article (https://doi.org/10.1007/s11356-020-07885-3) contains supplementary material, which is available to authorized users.

Agnieszka Konkolewska

akutr@amu.edu.pl

Arleta Małecka

arletam@amu.edu.pl

1 Department of Biochemistry, Adam Mickiewicz University in Poznan, Uniwersytet Poznanski 6 Street, 61-614 Poznan, Poland

2 Laboratory of Genome Biology, Adam Mickiewicz University in Poznan, Uniwersytet Poznanski 6 Street, 61-614 Poznan, Poland

3 Laboratory of RNA Biochemistry, Adam Mickiewicz University in Poznan, Uniwersytet Poznanski 6 Street, 61-614 Poznan, Poland

4 Department of Bioenergetics, Adam Mickiewicz University in Poznan, Uniwersytet Poznanski 6 Street, 61-614 Poznan, Poland yield (Weyens et al. 2009; Andersen et al. 2018). After emission to the environment, these elements can enter the food chain through plants, to be later accumulated in higher levels of consumers, posing a threat to animal and human health
5 Institute of Biology and Human Evolutionary, Adam Mickiewicz University in Poznan, Uniwersytet Poznanski 6 Street, 61-614 Poznan, Poland

6 Department of Trace Analysis, Faculty Chemistry, Adam Mickiewicz University in Poznań, Uniwersytet Poznanski 8 Street, 61-614 Poznan, Poland

7 Faculty of Natural Sciences, University of Silesia in Katowice, 40-032 Katowice, Poland

8 Laboratory of Biotechnology, Institute of Molecular Biology and Biotechnology, Adam Mickiewicz University in Poznan, Uniwersytet Poznanski 6 Street, 61-614 Poznan, Poland 
(Aelion and Davis 2007; Bhattacharyya and Jha 2012; Douay et al. 2013). Contaminated soil can be remediated with phytoextraction, which uses the natural or induced capacity of plants to uptake and accumulate metals from the soil (Jadia and Fulekar 2009). It is considered a low-cost alternative compared with available methods of remediation (Sarma 2011).

Two main factors which limit the phytoextraction rate are biomass production and metal accumulation in plant tissue. Additionally, because harvesting of plant roots in the process is not economically feasible, another aspect-metal translocation to aboveground organs - should be considered as the third most important factor. Thus, in order to increase the efficiency of the process and make it economically viable, both biomass production and/or metal accumulation should be improved together with translocation to aerial parts.

Plant ability to take up and accumulate trace metals efficiently in the aboveground tissue is often expressed as a bioconcentration coefficient/factor (BCF), i.e., the ratio of metal content in the shoot tissue to the content in soil (McGrath and Zhao 2003). Robinson et al. (2015) estimated that a $\mathrm{BCF}=14.8$ of plants that produced 5 tons $\mathrm{h}^{-1}$ would be needed in order to decrease the contamination by $50 \%$ in a $25-$ year period; but if the plant produced 10 tons $\mathrm{h}^{-1}$, a BCF = $7.4 \mathrm{t}$ only, for a soil contaminated with one metal to a depth of $20 \mathrm{~cm}$ at a soil density of $1.3 \mathrm{~g} \times \mathrm{cm}^{-3}$.

However, the selection of plants with an appropriate coefficient is not straightforward. Some plants endemic to soil enriched in minerals can accumulate high levels of metals. These so-called hyperaccumulators are characterized by a BCF coefficient of more than 1 (even reaching 50-100), whereas most plant species have a BCF factor for metals of $<1$ (Ali et al. 2013). The main physiological mechanisms underlying the trait of hyperaccumulation are enhanced uptake in roots, efficient xylem loading, and increased detoxification levels (Verbruggen et al. 2009, 2013).

Higher metal accumulation can be also obtained in plants by stimulation, e.g., with chelators or microorganisms, the strains of which secrete substances that promote metal mobilization in soil (Vamerali et al. 2010; Wood et al. 2016; Sobariu et al. 2017). Endophytic bacteria have developed several types of mechanisms by which they reduce the toxicity of metal ions. These include the transformation of metal ions into less toxic forms and metal sequestration in extracellular and intracellular polymers as well as precipitation, adsorption, or biomethylation (Rajkumar et al. 2013). In addition, microbial inoculation may have other positive effects on plants: reduction of stress propagation and increased biomass production (Etesami 2018). Rajkumar et al. (2013) showed an increase in phytostabilization potential for Brassica juncea, Luffa cylindrica and Sorgo halepense plants inoculated with the Ni resistant Bacillus megaterium SR28C isolate. The bacteria alleviated the toxicity of $\mathrm{Ni}$ by reducing its absorption and translocation in plants. Similarly, Srivastava and Singh
(2014) used bacteria immobilizing metal-Acinetobacter $\mathrm{sp}$. isolated from arsenic-contaminated soil- to improve plant growth and reduce heavy metal translocation to plant shoots, thus enhancing the potential for phytostabilization of Cicer arietinum grown on soils contaminated with arsenic. Moreover, research presented by Ma et al. (2015) using Psychrobacter sp. SRS8 and Pseudomonas sp. A3R3 bacteria isolated from serpentine soil revealed a significant effect on plant growth as well as translocation and accumulation of $\mathrm{Ni}$, $\mathrm{Zn}$, and Fe by Brassica juncea and Ricinus communis grown on metal-contaminated serpentine soil. Plant inoculation with bacteria significantly increased plant biomass and heavy metal accumulation compared with the unvaccinated control, which the authors attributed to bacterial production of metabolites that stimulate plant growth and/or mobilize metals. The Psychrobacter SRS8 strain showed the maximum increase in biomass of the tested plants, while Pseudomonas A3R3 displayed the maximum effect on heavy metal accumulation in both plants. However, both plant species showed low values of the bioconcentration factor $(<1)$ for $\mathrm{Ni}$ and $\mathrm{Fe}$, regardless of inoculation. The authors showed significant increase in the translocation coefficient (TF) for $\mathrm{Ni}$, while the $\mathrm{TF}$ value for $\mathrm{Zn}$ was reduced in both inoculated plant species.

Plant growth-promoting rhizobacteria (PGPR) were initially used in agriculture and forestry to increase productivity and disease resistance and to protect against stress associated with the presence of trace metals or low $\mathrm{pH}$ soils, but also due to flooding, organic toxic substances, high salinity, drought, and phytopathogens (Saleem et al. 2007; Glick 2010; Bhattacharyya and Jha 2012). PGPR influence plants by, e.g., increasing the pool of bioavailable phosphorus, nitrogen, and iron (with siderophore secretion) and producing plant hormones (gibberellins, cytokinins, auxins) (Ma et al. 2015, 2016). They also increase plant resistance, e.g., by decreasing ethylene level (through the synthesis of ACC deaminase) (Saleem et al. 2007; Sessitsch et al. 2013; Goswami et al. 2016). The PGPR include, among others, strains of Pseudomonas putida, Pseudomonas aeruginosa, Azospirillum brasilense, Serratia liquefaciens, and Enterobacter cloacae (Bhattacharyya and Jha 2012). As He et al. $(2009,2013)$ showed, the presence of endophytes can significantly affect the efficiency of phytoextraction. The authors (He et al. 2009) studied the effect of two cadmiumresistant strains Pseudomonas sp. RJ10 and the Bacillus sp. RJ16 on increasing the mobility of cadmium and lead in soil and promoting plant growth $\mathrm{Cd}$ and $\mathrm{Pb}$ uptake by a tomato cultivar with features of $\mathrm{Cd}$ hyperaccumulator. They observed an increase in available forms of $\mathrm{Cd}$ and $\mathrm{Pb}$ in inoculated soil, by $58-104 \%$ and $67-93 \%$, respectively, compared with unvaccinated controls. In the studied tomato plants, the increase in the content of $\mathrm{Cd}$ and $\mathrm{Pb}$ in aboveground ranged from 70 to over $110 \%$, respectively, in vaccinated plants growing in soil contaminated with heavy metals compared with non- 
inoculated plants. Inoculation with PGPR also has the potential to increase the efficiency of phytoremediation (He et al. 2013). The authors showed that inoculation of Brassica napus plants with Rahnella sp. JN6 alleviated the stress caused by the presence of metals due to ACC deaminase secreted by bacteria, and at the same time plants displayed increased root and shoot length and root biomass. Rape plants inoculated with the isolate JN6 had significantly higher concentrations and uptake of $\mathrm{Cd}, \mathrm{Pb}$, and $\mathrm{Zn}$ in both aboveground and root tissues than those without inoculation grown in soils amended with $\mathrm{Cd}, \mathrm{Pb}$, or $\mathrm{Zn}$. These results show that the bacteria can be used to improve bacterial phytoextraction of soils contaminated with $\mathrm{Cd}$ and $\mathrm{Pb}$. However, the optimization of parameters for inoculation of selected plants with microorganisms is difficult, the reason being that the influence of bacterial consortium depends on the inoculum density and plant species, as well as on the plant's stage of development (Karami and Shamsuddin 2010).

Plants' ability to accumulate metals is expressed normally as an average content of trace elements in grams of dry matter. A large dry biomass production per hectare is critical for soil remediation (Neugschwandtner et al. 2008). Under normal conditions, crop yields can be significantly improved by simultaneous intercropping of two different species through the efficient use of water, nutrients, and solar energy, compared with monoculture cropping (Mead and Willey 1980; Olowe and Adeyemo 2009; Temperton et al. 2007). The so-called companion planting (co-planting) reduces losses caused by diseases and parasites (Held et al. 2003; Wang et al. 2010; Liu et al. 2011). Crop co-planting may affect phytoextraction of metals from soil because coexistence of multiple plant species may change rhizosphere microorganisms, soil enzyme activities, and the abiotic micro-environment, and thus may affect the metal bioavailability in rhizosphere soil (Khan 2005; Yang et al. 2009).

The use of crops in a co-planting system for the phytoextraction of metals has been studied for about 10 years. However, the aim of co-planting was mainly to increase phytoextraction efficiency of hyperaccumulators and metalaccumulating plants by improving their physiological state. Experiments have shown that some plant species can intensively export $\mathrm{H}^{+}$ions and/or exude low molecular weight organic acids (e.g., acetic, oxalic, fumaric, citric, and tartaric acids) into soil, which can increase metal mobility either directly or indirectly by affecting microbial activity (Chiang et al. 2006; Evangelou et al. 2006; Duarte et al. 2007). Moreover, $\mathrm{H}^{+}$can replace cations and make metal cations more bioavailable (Marques et al. 2009). For example, the hyperaccumulator Sedum alfredii was cultivated with a lowaccumulating variety of Zea mays (Wu et al. 2007), or an accumulating variety of Nicotiana tabacum with nonaccumulating Kummerowia striata (Liu et al. 2011). The design to match species and varieties with different abilities to accumulate metals is based on a specific phenomenon: although co-planting physically reduces density and biomass of an accumulating plant, by incorporating a second species, the resulting yield of trace metals in the harvest can be similar to that from a monoculture (Jiang et al. 2010). Another approach involves co-planting to increase the yield of the crop grown on contaminated soil while maintaining a low accumulation of metals in the collected material (Yang et al. 2012).

The aim of this study was to improve the efficiency of phytoextraction of trace elements (zinc, lead, and cadmium) by combining assisted phytoextraction and a co-planting culture. In the course of the pot experiment, B. juncea was grown individually, with Zea mays or with Medicago sativa. Half of the pots were inoculated with a plant growth-promoting rhizobacteria (PGPR) inoculation, Burkholderia phytofirmans PsJN" ${ }^{\mathrm{T}}$.

\section{Material and methods}

\section{Soil description}

Around $300 \mathrm{~kg}$ of surface soil was collected (0 to $20 \mathrm{~cm}$ depth) from a site situated between the towns of Bytom and Piekary Śląskie, in the Upper Silesia Industrial Region of southern Poland. This site is located in proximity to a former mine and smelter area, and was used for agricultural purposes until the early 1980 s, when farming ceased due to poor crop yield. The mine and smelter operated for approximately 70 years, and the primary minerals of concern were zinc, lead, cadmium, ore, dolomite, silt, and gravel. The metal ores were thermally processed on-site, applying the Welz and Doerschel process (Stuczyński et al. 2000). Mining activities resulted in land deformations, subsidence, and a considerable lowering of the groundwater table. In 1989, production stopped, all the facilities were closed down and dismantled, and the revitalization of the area (460 ha) was attempted. Many of the old tailing piles and surrounding wastelands are overgrown with grasses and short trees, although a large area remains unvegetated (Kucharski et al. 2005). Garden soil (ecological universal soil, $\mathrm{pH}$ 5.5-6.5, obtained from a local distributor) was used to dilute the contaminated soil collected from Piekary Ślaskie. Soil was stored at room temperature, thoroughly mixed in the appropriate proportions (1:1 and 1:3), sieved $(3 \mathrm{~mm})$, and used for further experiments.

\section{Physicochemical soil parameters}

Soil $\mathrm{pH}$ was measured in deionized water $(1: 2.5 \mathrm{~m} / \mathrm{v})$ and $1 \mathrm{M}$ $\mathrm{KCl}(1: 2.5 \mathrm{~m} / \mathrm{v})$ with a combination glass/calomel electrode and a $\mathrm{pH} /$ conductivity meter (CPC-505, Elmetron, Poland) at room temperature after $24 \mathrm{~h}$ of equilibration. The electrical conductivity (EC) was determined in deionized water 
suspension (soil-to-solution ratio $1: 2.5 \mathrm{~m} / \mathrm{v}$ ) at room temperature after $24 \mathrm{~h}$ of equilibration by using a glass conductivity cell (EC-60, Elmetron, Poland) and a pH/conductivity meter (CPC-505, Elmetron, Poland). The content of bioavailable forms of metals was obtained using extraction with $0.01 \mathrm{M}$ $\mathrm{CaCl}_{2}$. Extraction was conducted with $3 \mathrm{~g}$ of soil $(<2.0 \mathrm{~mm})$ and $30 \mathrm{~mL} 0.01 \mathrm{M} \mathrm{CaCl}_{2}$ for $2 \mathrm{~h}$. The total metal content was determined after digestion of soil ground to $<0.25 \mathrm{~mm}$ by using microwave mineralization (ETHOS 1, Milestone, Italy) according to the procedure provided by the manufacturer (concentrated $\mathrm{HNO}_{3}$ and $\mathrm{H}_{2} \mathrm{O}_{2}, 4: 1 \mathrm{v} / \mathrm{v}$ ). The concentration of metals was analyzed in the extracts and digests by using flame atomic absorption spectrophotometry (iCE 3500 FAAS, Thermo Scientific, USA). The reference soil material (NCS DC 77302, China National Analysis Center for Iron and Steel, Beijing, China) was used for quality assurance of analytical data.

\section{Germination tests}

The following plant seeds were used: Brassica juncea (L.) Czern. "Małopolska," Medicago sativa L. "Sanditi" (Barenbrug, Poland), Zea mays L. "Codimon" C1 INFLUX XL (Oseva, Poland). Bacteria Burkholderia phytofirmans $\mathrm{PsJN}^{\mathrm{T}}$ (the strain was kindly provided by prof. Angela Sessitsch from the Austrian Institute of Technology $\mathrm{GmbH}$ ) were grown in TSB liquid media (Merck) until the exponential growth phase, as measured by $\mathrm{OD}_{600}$. Germination tests were carried out using PhytoToxKit plates (Tigret, Poland), according to the manufacturer's instruction. A buffer $(30 \mathrm{~mL})$ containing $1.48 \mathrm{~g} \mathrm{Na}_{2} \mathrm{HPO}_{4} \times 12 \mathrm{H}_{2} \mathrm{O}, 0.28 \mathrm{~g} \mathrm{KH}_{2} \mathrm{PO}_{4}, 0.05 \mathrm{~g}$ $\mathrm{NaCl}$, and $0.1 \mathrm{~g} \mathrm{NH}_{4} \mathrm{Cl}$ suspended in $1 \mathrm{~L}$ of sterile water was mixed with $85 \mathrm{~g}$ of garden soil or garden soil mixed in 1:1 or $1: 3 \mathrm{w} / \mathrm{w}$ proportions with contaminated soil. The preliminary tests showed that the growth of the crop plants (Zea mays, Brassica juncea, and Medicago sativa) was heavily inhibited on contaminated soil collected from Piekary Śląskie. Because germination tests showed a strong negative effect of the 1:3 mixture of soil (3 parts by weight of soil from Piekary Ślaskie and 1 part by weight of garden soil), especially on the growth and development of $B$. juncea, it was decided that long-term pot cultivation would be conducted on a 1:1 mixture. Then, 10 or 7 seeds of B. juncea, M. sativa, or Z. mays were sowed on each pot, respectively. The choice of inoculum density was based on previous studies of this strain (Compant et al. 2008). It was decided to assess the influence of using the inoculum at four densities: $7.06 \times 108,7.06 \times 10^{8}, 1.41 \times 10^{9}, 2.82 \times 10^{9}$, $5.65 \times 10^{9}$ ( $\mathrm{CFU} \mathrm{kg}{ }^{-1}$ of soil). Inoculum density was selected for further studies, which showed the lowest negative impact on germination of three species in this experimental system, $1.41 \times 109 \mathrm{CFU} \mathrm{kg}^{-1}$ soil. Non-inoculated buffer was used for the control plates. To minimize the level of stress at the early stage of plant development (simultaneous abiotic stress due to the presence of metals and biotic due to bacterial colonization), plant inoculation was carried out 7 days after sowing. The germination tests were performed in triplicates.

\section{Greenhouse pot experiments}

The pot culture was carried out in an automated greenhouse at the Greater Poland Center for Advanced Technologies (Poznań, Poland). Growing conditions: temperature between 6:00 a.m. $-22: 00$ p.m. $-21.5-22.5{ }^{\circ}$ C, $22: 30$ p.m.-5:30 a.m.$18-19.5{ }^{\circ} \mathrm{C}$; humidity: $35-40 \%$; complementary lighting: from 6:00 a.m. to 22:00 p.m. to $100 \mathrm{Wm}^{-2}$. Seeds were sown in 1-L pots. Plant seeds were inserted into the pots to a depth of $0.5 \mathrm{~cm}$ : 12 seeds of $B$. juncea, 6 seeds of $B$. junce $a+2$ seeds of $Z$. mays, 6 seeds of $B$. juncea +10 seeds of M. sativa. After 2 weeks of cultivation, the number of plants was limited by half in pots by cutting the shoot near the ground. Ultimately, the experimental setup consisted of 3 cultivation variants conducted independently for control plants and inoculated with PGPR bacteria: 6 pots with only $B$. juncea plants (6 plants in each), 3 pots of $B$. juncea (3 plants in each) plus of $Z$. mays ( 1 plant in each), and 3 pots of $B$. juncea ( 3 plants in each) plus $M$. sativa (5 plants in each). The plants were watered three times a week using a mixture with Florovit Universal liquid fertilizer (INCO Group, Poland) at $5 \mathrm{~mL}$ per liter of distilled water. After a week, plants were inoculated with $B$. phytofirmans suspended in $30 \mathrm{~mL}$ buffer described in the "Germination tests" section, using an inoculum density of $1.41 \times 109 \mathrm{CFU} \mathrm{kg}^{-1}$ soil. Uninfected buffer was used in control pots. Inoculated and non-inoculated plants were grown in separate flooding tables. Cultivation was carried out for 6 weeks from sowing to harvest. As part of each experimental series, each variant was represented by three pots, prepared and treated in the same way. The described pot experiment was carried out three times in 4 months (from May to August).

\section{Sample preparation}

Plant material (roots, stems, and leaves) was rinsed with distilled water, gently dried on blotting paper, weighed, and dried at $70 \pm 2{ }^{\circ} \mathrm{C}$. The dried samples were mineralized in a microwave digestion oven (Ethos One, Milestone, Italy). The samples for digestion were prepared as follows: approximately $0.5 \mathrm{~g}$ of the sample was transferred to digestion vessels and $5 \mathrm{~mL}$ of $65 \%$ nitric acid (Merck, Germany) was added to each vessel. The microwave oven heating program proceeded in steps: (1) ramp time of $20 \mathrm{~min}$ to reach $1500 \mathrm{~W}$, (2) hold time of $30 \mathrm{~min}$ at $1500 \mathrm{~W}$, and (3) cooling for $30 \mathrm{~min}$. The temperature during the digestion process was $220^{\circ} \mathrm{C}$. After mineralization, samples were quantitatively transferred to $10-\mathrm{mL}$ flasks and filled with deionized water. In parallel, the procedural blanks, including the same reagents as the samples, were 
prepared and digested in the same way as the samples in each digestion run.

\section{Analytical procedure}

An inductively coupled plasma mass spectrometry (ICP-MS) model Elan DRC II (Perkin-Elmer Sciex, Canada) was used to determine the concentration of $\mathrm{Cd}, \mathrm{Cu}, \mathrm{Pb}$, and $\mathrm{Zn}$ in the mineralized plant tissues. An ICP-MS spectrometer equipped with a Meinhard concentric nebulizer, cyclonic spray chamber, Pt cones, and quadrupole mass analyzer was used for this study. Argon with a purity of $99.999 \%$ was used as a nebulizer, auxiliary, and plasma gas (Linde Gaz, Poland). As the DRC reaction gas, high-purity ammonia (99.999\%) was used. Deionized water was used throughout the experiment. Treated and control plant materials were analyzed ex vivo by an LA-ICP-MS. The ICP-MS spectrometer model Elan DRC II (Perkin-Elmer Sciex, Canada) was equipped with an Nd:YAG laser ablation system (LSX-500, CETAC Technologies, Omaha, NE, USA) operating at a wavelength of $266 \mathrm{~nm}$. The accuracy of the results obtained with the LAICP-MS method depends on the following: distribution of the analyzed on a sample's surface, homogeneity of the matrix, and geometry of the sample (Hanć et al. 2016). The exact description for the ICP-MS and LA-ICP-MS parameter optimization has been described in Supplementary Table 1.

\section{Analytical performance}

After calibration, and also during the analysis, measurements were controlled by analysis of standard solutions at concentrations of $1 \mu \mathrm{g} \mathrm{L}^{-1}$ or $5 \mu \mathrm{g} \mathrm{L}^{-1}$ and certified reference materials after each batch of fifteen samples. The calibration curves for the determined elements were linear in the range of calibration standards. The correlation coefficient $R$ exceeded a value of 0.999 . The trueness of the analytical results was assessed using the reference material NIST SRM 1515 Apple Leaves and NIST SRM Spinach Leaves 1575a. The accuracy of the method for the investigated elements was evaluated by determining the percentage bias between the measured concentration of the applied certified reference materials (CRMs) and its certified value. The bias represents the difference between the CRM elemental concentration measured using ICP-MS and the certified value, which is as follow: $1.5 \%$ for $\mathrm{Cd}, 2.3 \%$ for $\mathrm{Cu}, 1.7 \%$ for $\mathrm{Pb}$, and $2.5 \%$ for $\mathrm{Zn}$. The limits of detection (LOD) for the determined elements were counted according to $\mathrm{LOD}=3.3 S / b$, where $S$ means standard deviation of the result obtained for the blank samples and $b$ is the sensitivity. The LODs for the ICP-MS method were found to be $0.02 \mu \mathrm{g} \mathrm{g}^{-1}(\mathrm{Cd}), 0.05 \mu \mathrm{g} \mathrm{g}^{-1}(\mathrm{Cu})$, $0.008 \mathrm{\mu g} \mathrm{g}^{-1}(\mathrm{~Pb})$, and $0.01 \mathrm{mg} \mathrm{g}^{-1}(\mathrm{Zn})$. LOQ values were calculated as three times the LOD values. Precision was calculated as the relative standard deviation expressed as \%. As a result of the analysis, the precision values were calculated for $\mathrm{Cd}(1.2 \%), \mathrm{Cu}(2.8 \%), \mathrm{Pb}(1.7 \%)$, and $\mathrm{Zn}(2.4 \%)$.

\section{Chlorophyll content measurement}

The level of chlorophyll $a$ and $b$ was estimated using DMSO according to the method described by Ronen and Galun (1984). Leaves (200 mg) from B. juncea plants were cut into small $\left(4-16 \mathrm{~mm}^{2}\right.$ ) pieces and placed in a vial with $5 \mathrm{~mL}$ DMSO. Three replicates of samples were incubated in a water bath at $65^{\circ} \mathrm{C}$ for $120 \mathrm{~min}$. Chlorophyll extract was transferred to a cuvette and spectrophotometric readings were made at $649 \mathrm{~nm}$ and $665 \mathrm{~nm}$ using a UV-VIS spectrophotometer (Shimadzu Scientific Instruments, Japan).

\section{Measurements of the level of reactive oxygen species}

Reactive oxygen species (ROS) levels were determined in $B$. juncea shoots grown with $Z$. mays and $M$. sativa plants, inoculated and non-inoculated with PGPR. Superoxide anion content was determined according to Doke (1983) at $580 \mathrm{~nm}$. The plant shoots $(0.5 \mathrm{~g})$ were placed in test tubes and filled with $7 \mathrm{~mL}$ of mixture containing $50 \mathrm{mM}$ phosphate buffer ( $\mathrm{pH} 7.8$ ), $0.05 \%$ NBT (nitro blue tetrazolium) and $10 \mathrm{mM}$ of $\mathrm{NaN}_{3}$. Next, the test tubes were incubated in darkness for $5 \mathrm{~min}$, after which and then $2 \mathrm{~mL}$ of the solution was taken from the tubes heated at $85^{\circ} \mathrm{C}$ for $10-15 \mathrm{~min}$ and cooled in ice for $5 \mathrm{~min}$. The absorbance was measured using spectrophotometry (SHIMADZU UV-1800, Japan) at $580 \mathrm{~nm}$ against the control.

Hydrogen peroxide content was determined according to Patterson et al. (1984). The plant shoots were homogenized in 5\% TCA (trichloroacetic acid). The homogenate was centrifuged twice at $13,000 \mathrm{~g}$ for $20 \mathrm{~min}$. The level of hydrogen peroxide was determined in the supernatant by the spectrophotometric method at $508 \mathrm{~nm}$. The reaction mixture contained $50 \mathrm{mM}$ phosphate buffer ( $\mathrm{pH} 8.4$ ), a reagent containing $0.6 \mathrm{mM}$ 4-(-2 pyridylazo) resorcinol, $0.6 \mathrm{mM}$ potassium-titanium oxalate in 1:1. A corresponding concentration of $\mathrm{H}_{2} \mathrm{O}_{2}$ was determined against the standard curve of $\mathrm{H}_{2} \mathrm{O}_{2}$.

\section{Determination of antioxidative enzyme activities}

Plant shoots $(0.5 \mathrm{~g})$ were homogenized in isolation buffer $50 \mathrm{mM} \mathrm{K} \mathrm{HPO}_{3} / \mathrm{KH}_{2} \mathrm{PO}_{4}, \mathrm{pH} 7.0 ; 1 \%$ Triton $\mathrm{X}-100 ; 17 \mathrm{mM}$ 2-mercaptoethanol, and $1 \mathrm{mM}$ ascorbic acid at $4{ }^{\circ} \mathrm{C}$. The homogenate was centrifuged twice at $13,000 \mathrm{~g}$ for $20 \mathrm{~min}$. The supernatant activity of antioxidant enzymes was determined. Activity of SOD was assayed according to Beauchamp and Fridovich (1971), with slight modification. The activity was assayed by measuring its ability to inhibit the photochemical reduction of NBT. The reaction mixture contained $13 \mathrm{mM}$ riboflavin, $13 \mathrm{mM}$ methionine, $63 \mathrm{mM} \mathrm{NBT}$, and $50 \mathrm{mM}$ 
potassium phosphate buffer ( $\mathrm{pH}$ 7.8). Absorbance at $560 \mathrm{~nm}$ was then measured. One unit of SOD activity was defined as the amount of enzyme, which causes a $50 \%$ decrease of the inhibition of NBT reduction. Activity of CAT was determined according to Aebi (1983) at $240 \mathrm{~nm}$. The activity of CAT was determined by directly measuring the decomposition of $\mathrm{H}_{2} \mathrm{O}_{2}$ at $240 \mathrm{~nm}$ for $3 \mathrm{~min}$ in $50 \mathrm{mM}$ phosphate buffer ( $\mathrm{pH} \mathrm{7.0)}$ containing $5 \mathrm{mM} \mathrm{H}_{2} \mathrm{O}_{2}$ and enzyme extract. CAT activity was determined using an extinction coefficient of $36 \mathrm{mM}^{-1} \mathrm{~cm}^{-1}$ for $\mathrm{H}_{2} \mathrm{O}_{2}$. Activity of APOX was determined according to Nakano and Asada (1981). The method relies on monitoring the rate of ascorbate oxidation at $290 \mathrm{~nm}$ (extinction coefficient of $2.9 \mathrm{mM}^{-1} \mathrm{~cm}^{-1}$ ) for $3 \mathrm{~min}$. The reaction mixture consisted of $25-50 \mu \mathrm{L}$ supernatant, $50 \mathrm{mM}$ phosphate buffer ( $\mathrm{pH} 7.0$ ), $10 \mathrm{mM} \mathrm{H}_{2} \mathrm{O}_{2}, 0.2 \mathrm{mM}$ ascorbate, and $0.2 \mathrm{mM}$ EDTA.

\section{Protein quantification}

Total soluble protein contents were determined according to Bradford (1976), using the BioRad assay kit with bovine serum albumin as a calibration standard.

\section{Dehydrogenase activity in soil}

Measurement of dehydrogenase activity by microorganisms in soil has the potential to serve as a useful indicator of microbial activity. Soil dehydrogenase activity was measured by the reduction of 2,3,5-triphenyl tetrazolium chloride (TTC) to 1,3,5-triphenyl formazan (TPF) with the Penrose and Glick method (Penrose and Glick 2003). A soil sample (2.5 g) was incubated for $24 \mathrm{~h}$ at $23^{\circ} \mathrm{C}$ in $5 \mathrm{~mL}$ of $1 \%$ TTC solution. After incubation, the sample was blended with $10 \mathrm{~mL}$ of methanol to extract TPF and shaken for $1 \mathrm{~min}$, then filtered. Absorbance in the extract was measured at $485 \mathrm{~nm}$. Finally, soil dehydrogenase activity was calculated as $\mu \mathrm{g}$ TPF $\mathrm{g}^{-1}$ dry soild ${ }^{-1}$.

\section{Western blot and immunodetection of CuZnSOD and FeSOD}

Western blot analysis was performed for protein extracts from shoot seedlings of $B$. juncea, grown in a monoculture and in co-planting culture with M. sativa and Z. mays, in the presence and non-presence PGPR. RIPA buffer $(150 \mathrm{mM} \mathrm{NaCl}, 1 \%$ Triton X-100, $0.5 \%$ Na deoxycholate, $0.1 \%$ SDS, $50 \mathrm{mM}$ Tris, $\mathrm{pH}$ 8.0) was used to lyse the cells. The protein concentrations were determined using the Bradford method and $50 \mu \mathrm{g}$ of each fraction was loaded on the gel. Proteins were separated on a $12 \%$ resolving SDS-PAGE gel. Immunodetection was carried out using primary polyclonal antibodies raised against $\mathrm{CuZnSOD}$ (chloroplastic $\mathrm{Cu} / \mathrm{Zn}$ superoxide dismutase) or FeSOD (chloroplastic Fe superoxide dismutase) (Agrisera antibodies) at a dilution of 1:1000 and goat anti-rabbit horseradish peroxidase-conjugated secondary antibodies (BioRad) at a dilution of 1: 50000. CuZnSOD and FeSOD bands were visualized using the Amersham ECL system and quantified digitally using the Scan Pack 3.0 program. The results are presented as the mean \pm S.E. obtained from 2 independent experiments (plant growths and preparations), and each determination was performed at least in triplicate throughout the study.

\section{Statistical analysis}

Experiments were carried out in three biological and technical repetitions. Average values ( $\pm \mathrm{SD}$, standard deviation) are given in tables and diagrams. The results were analyzed using the IBM SPSS Statistics program (Version 22 for Windows). Statistically significant differences between the variants were analyzed using the one-way ANOVA method, at $p<0.05$, and using the post hoc b-Tukey test. If no letters are marked on the charts, it means that either the b-Tukey test did not show a statistically significant difference or it was impossible to compare these variants due to the too low number of independent measurements. For experiments using germination tests and pot culture, box plots were used to show the distribution of the characteristics of the analyzed samples, in the case of collecting $n \geq 5$ samples for a given variant. In other cases, the data are presented as mean values $( \pm \mathrm{SD})$. Box plots have been constructed as follows: the top and bottom sides of the rectangle are equal to Q3 and Q1 quartiles, a median is marked in the middle of the rectangle, the width of the box corresponds to the value of the interquartile range (IQR), i.e., the difference between the third and the first quartiles, whiskers (upper and lower) show the range of the highest and lowest measurements lying within $1.5 * \mathrm{IQR}$, single points are measurements outside the range of $1.5 * \mathrm{IQR}$ (outside internal limits).

\section{Results}

The parameters of soil used in the course of experiments are presented in Table 1. Soil collected from Piekary Ślaskie with garden soil in the mixture of 1:1 had a pH of 6.90 and was enriched in Cd (22.46 mg kg$\left.{ }^{-1} \mathrm{DW}\right), \mathrm{Pb}\left(615 \mathrm{mg} \mathrm{kg}^{-1} \mathrm{DW}\right)$, and $\mathrm{Zn}\left(1822 \mathrm{mg} \mathrm{kg}^{-1} \mathrm{DW}\right)$. The results indicate that the level of the total metal content for the three elements in the soil was exceeded: zinc (sixfold), lead (sixfold), and cadmium (fivefold).

The average content of metals $(\mathrm{Cu}, \mathrm{Cd}, \mathrm{Zn}, \mathrm{Pb})$ in $B$. juncea shoots was higher by about fivefold than their content in $Z$. mays and $M$. sativa with the exception of $\mathrm{Pb}$ content in $M$. sativa and $\mathrm{Cu}$ in Z. mays (Fig. 1). Microbial inoculation generally increased metal content in B. juncea. There was no statistically significant impact of companion planting 
Table 1 Properties of soil used in cultivation of prepared mixture (1:1) from garden soil and soil collected from Piekary Śląskie

\begin{tabular}{|c|c|c|c|c|c|}
\hline & $\begin{array}{l}\text { Total content } \\
\left(\mathrm{mg} \mathrm{kg}^{-1} \text { of } \mathrm{DW}\right)\end{array}$ & $\begin{array}{l}\text { Bioavailable metal content } \\
\left(\mathrm{mg} \mathrm{kg}^{-1} \text { of DW) }\right.\end{array}$ & $\mathrm{pH}_{\mathrm{H} 2 \mathrm{O}}$ & $\mathrm{pH}_{1 \mathrm{M} \mathrm{KCl}}$ & $\mathrm{EC}\left(\mu \mathrm{S} \mathrm{cm} \mathrm{cm}^{-1}\right)$ \\
\hline $\mathrm{Cd}$ & $22.46 \pm 1.76$ & $0.696 \pm 0.023$ & 6.90 & 6.80 & 1203.89 \\
\hline $\mathrm{Cu}$ & $17.19 \pm 1.09$ & $0.295 \pm 0.069$ & & & \\
\hline $\mathrm{Fe}$ & $10,573 \pm 903$ & $5.75 \pm 1.82$ & & & \\
\hline $\mathrm{Mg}$ & $1965 \pm 15$ & $177.3 \pm 3.1$ & & & \\
\hline $\mathrm{Mn}$ & $484 \pm 26$ & $25.24 \pm 0.78$ & & & \\
\hline $\mathrm{Pb}$ & $615 \pm 36$ & $2.52 \pm 0.79$ & & & \\
\hline $\mathrm{Zn}$ & $1822 \pm 166$ & $54.1 \pm 6.9$ & & & \\
\hline
\end{tabular}

cultivation on the content of metals in $B$. juncea plants. The highest accumulation was observed for $\mathrm{Zn}$ and it was about 50 to 240 times higher in B. juncea shoots than other elements, while the lowest accumulation was found for $\mathrm{Pb}$.

No significant differences were observed in the root length of the plants inoculated with PGPR and under the influence of co-planted culture (Fig. 2). In the case of stems, the most positive result was observed for variant $B$. juncea with coplanting with $Z$. mays, both inoculated and non-inoculated bacteria. Co-planting culture of $B$. juncea and Z. mays plants had the greatest impact on the fresh mass, whereas in the other variants, no significant differences were observed. Inoculation with PGPR bacteria did not increase fresh weight in the tested plants. The greatest effects of coordinate cultivation and inoculation with the Burkholderia phytofirmans $\mathrm{PsJN}^{\mathrm{T}}$ strain can
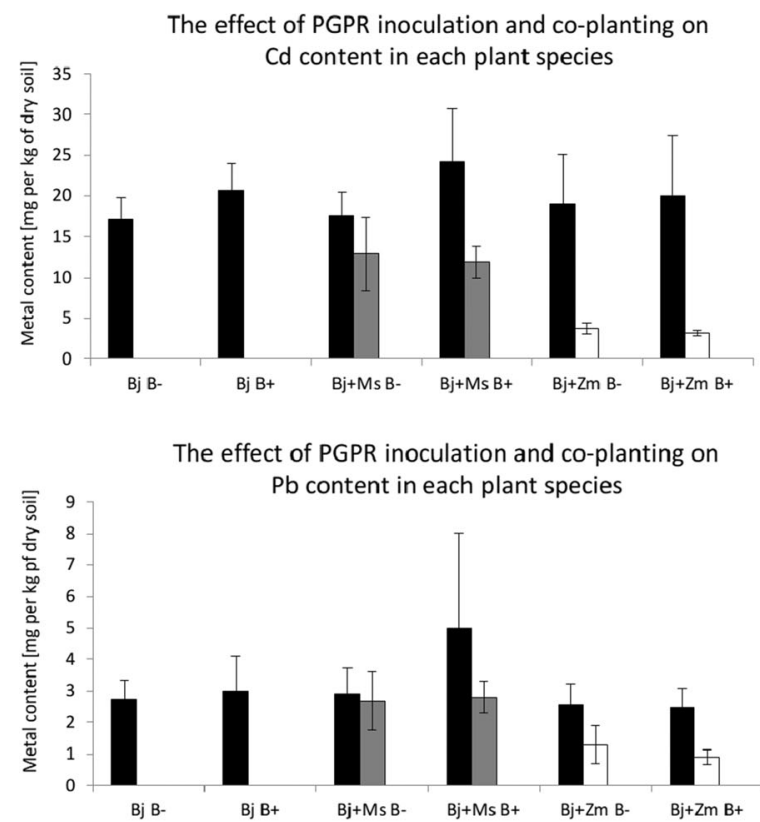

Fig. 1 Influence of inoculation of Burkholderia phytofirmans and coplanting cultivation $(\mathrm{Bj}+\mathrm{Zm} ; \mathrm{Bj}+\mathrm{Ms})$ on the metal content $(\mathrm{Cu}, \mathrm{Cd}$, $\mathrm{Pb}, \mathrm{Zn}$ ) in shoots of plants B. juncea, $M$. sativa, and Z. mays grown in pots with garden soil and from Piekary Śląskie (MIXTURE 1:1) in variants: Bj be seen when measuring the dry weight of plant seedlings. The dry mass of seedlings in variants $B$. juncea with $Z$. mays and $B$. juncea with M. sativa, both with and without bacteria, was on average 1.5-fold higher compared with control plants. The content of chlorophyll $a$ and $b$ increased significantly in only one research variant: $B$. juncea with $Z$. mays inoculated with PGPR. In other variants, a decrease in chlorophyll content was observed in the case of bacterial inoculation.

In most research variants, an increase in the level of ROS was observed in response to both biotic and abiotic stress factors (Fig. 3). The superoxide anion level in B. juncea was increased for PGPR inoculation variants (" $\mathrm{Bj} \mathrm{B}+$, , " $\mathrm{Bj}+\mathrm{Zm}$ $\mathrm{B}+$, , "Bj + Ms B+"), compared with the corresponding noninoculation variants (" $\mathrm{Bj} \mathrm{B}-$, , " $\mathrm{Bj}+\mathrm{Zm} \mathrm{B}-$, , " $\mathrm{Bj}+\mathrm{Ms} \mathrm{B}-$-") on average from 1 to 4 times. At the same time, a reduction in
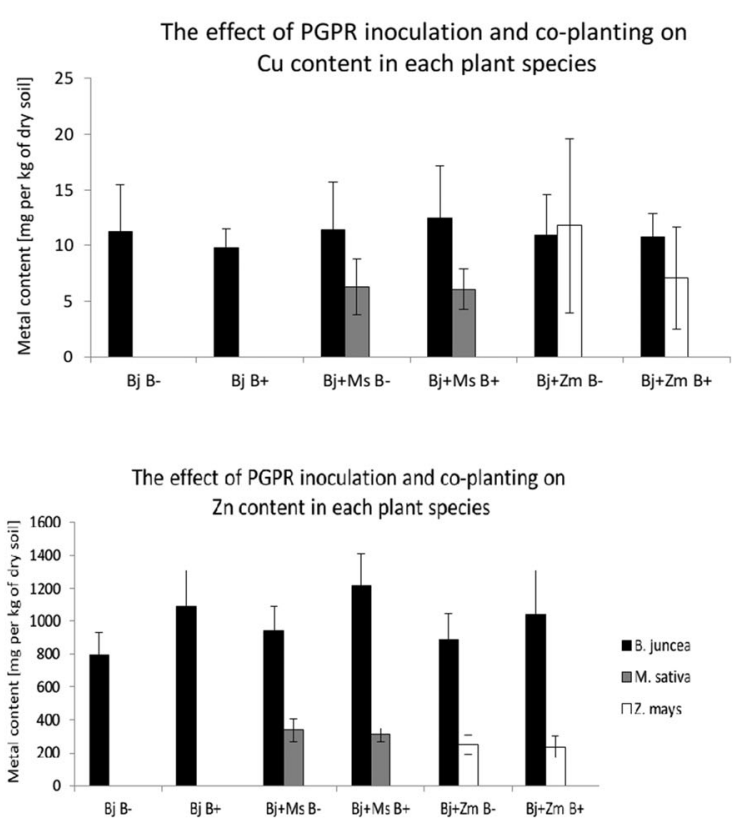

$\mathrm{B}-, \mathrm{Bj} \mathrm{B}+, \mathrm{Bj}+\mathrm{Ms} \mathrm{B}-, \mathrm{Bj}+\mathrm{Ms} \mathrm{B}+, \mathrm{Bj}+\mathrm{Zm} \mathrm{B}-, \mathrm{Bj}^{+} \mathrm{Zm} \mathrm{B}+. \mathrm{Bj}-B$. juncea, Ms - M. sativa, Zm - Z. mays, "B-" - without bacterial inoculation, "B+" - inoculated plants. Mean values of three replicates $( \pm$ SD) 

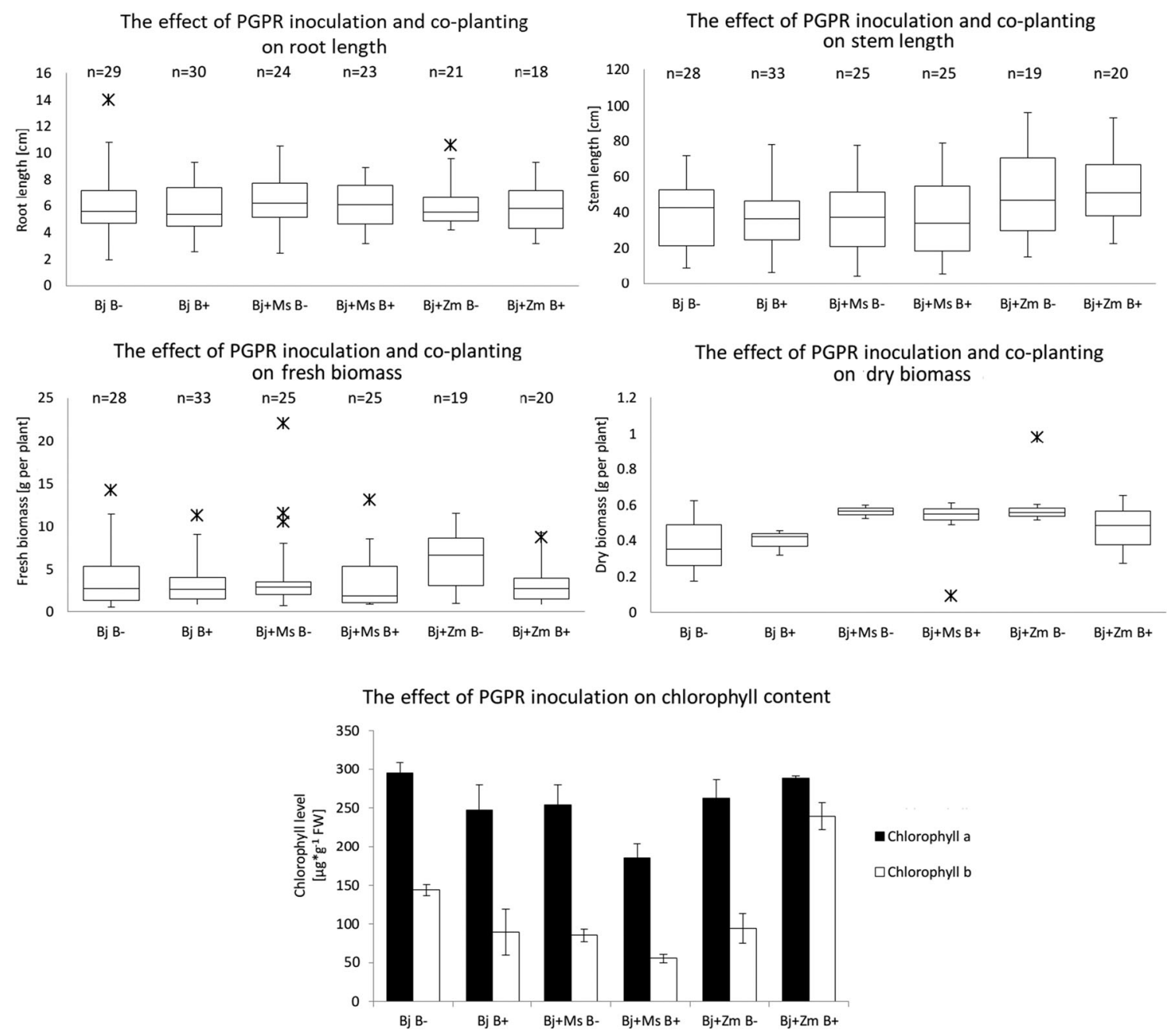

Fig. 2 Effect of Burkholderia phytofirmans inoculation and co-planting cultivation on plant growth parameters (root and stem length; fresh and dry biomass of cuttings) and chlorophyll content in the leaves of $B$. juncea, M. sativa, and Z. mays. Plants grown in pots with garden soil

and from Piekary Śląskie (MIXTURE 1: 1) in variants: $\mathrm{Bj} B-, \mathrm{Bj} B+, \mathrm{Bj}$ $+\mathrm{Ms} \mathrm{B}-, \mathrm{Bj}+\mathrm{Ms} \mathrm{B}+, \mathrm{Bj}+\mathrm{Zm} \mathrm{B}-, \mathrm{Bj}+\mathrm{Zm} \mathrm{B}+\mathrm{Bj}-$ B. juncea, $\mathrm{Ms}-\mathrm{M}$. sativa, $\mathrm{Zm}-\mathrm{Z}$. mays, "B-" - without bacterial inoculation, "B+" - inoculated plants. Mean values of three replicates $( \pm \mathrm{SD})$

the hydrogen peroxide level and CAT activity was observed in variants after inoculation with PGPR (except for "Bj B+"). In plants inoculated with PGPR (Fig. 3), an increased level of $\mathrm{O}_{2}{ }^{\circ}$ - and SOD activity as well as reduced CAT activity was observed compared with the control plants for each cultivation variant, except for the variant of simultaneous cultivation of $B$. juncea and $Z$. mays ("Bj $+\mathrm{Zm}$ "). There were no significant differences in the activity of the third important antioxidant enzyme-APOX - in either inoculated or control plants. In addition, " $\mathrm{Bj}+\mathrm{Zm}$ " was the variant from which the smallest number of $B$. juncea plants was harvested after cultivation, suggesting a high level of oxidative stress. We observed the effect of the Burkholderia phytofirmans $\mathrm{PsJN}^{\mathrm{T}}$ strain on morphological changes of $B$. juncea leaves and flowers. We noticed the positive effect of PGPR bacteria on plant development. The violet coloration of the leaves was a frequent symptom of stress, characteristic of plants without inoculation. In the case of inoculated plants, violet coloration of the leaves

was only rarely observed. The most common symptom of stress in this group of plants was chlorosis.

The level of CuZnSOD protein was decreased in B. juncea plants inoculated with phytofirmans $\mathrm{PsJN}^{\mathrm{T}}$ strain, in comparison with non-inoculated plants, in variants grown in monoculture and co-planted with $M$. sativa. Regarding the FeSOD level, the differences were not statistically significant (Fig. 3).

We noticed that inoculation with the PGPR bacteria $B$. phytofirmans $\mathrm{PsJN}^{\mathrm{T}}$ strain led to an increase in phytoextraction efficiency in most cases (Table 2). The highest negative effect of inoculation was observed for the yield of $B$. juncea plants co-planted with $Z$. mays for $\mathrm{Cu}$ and $\mathrm{Pb}$ metals. However, the total hypothetical metal yield for this variant (sum of $B$. juncea and $Z$. mays yield) showed an increase in phytoextraction efficiency for $\mathrm{Zn}$, while for $\mathrm{Cu}$ and $\mathrm{Pb}$, no significant differences were observed. The highest efficiency of phytoextraction was obtained in the variant of the $B$. juncea co-planted with $M$. sativa combined with PGPR 


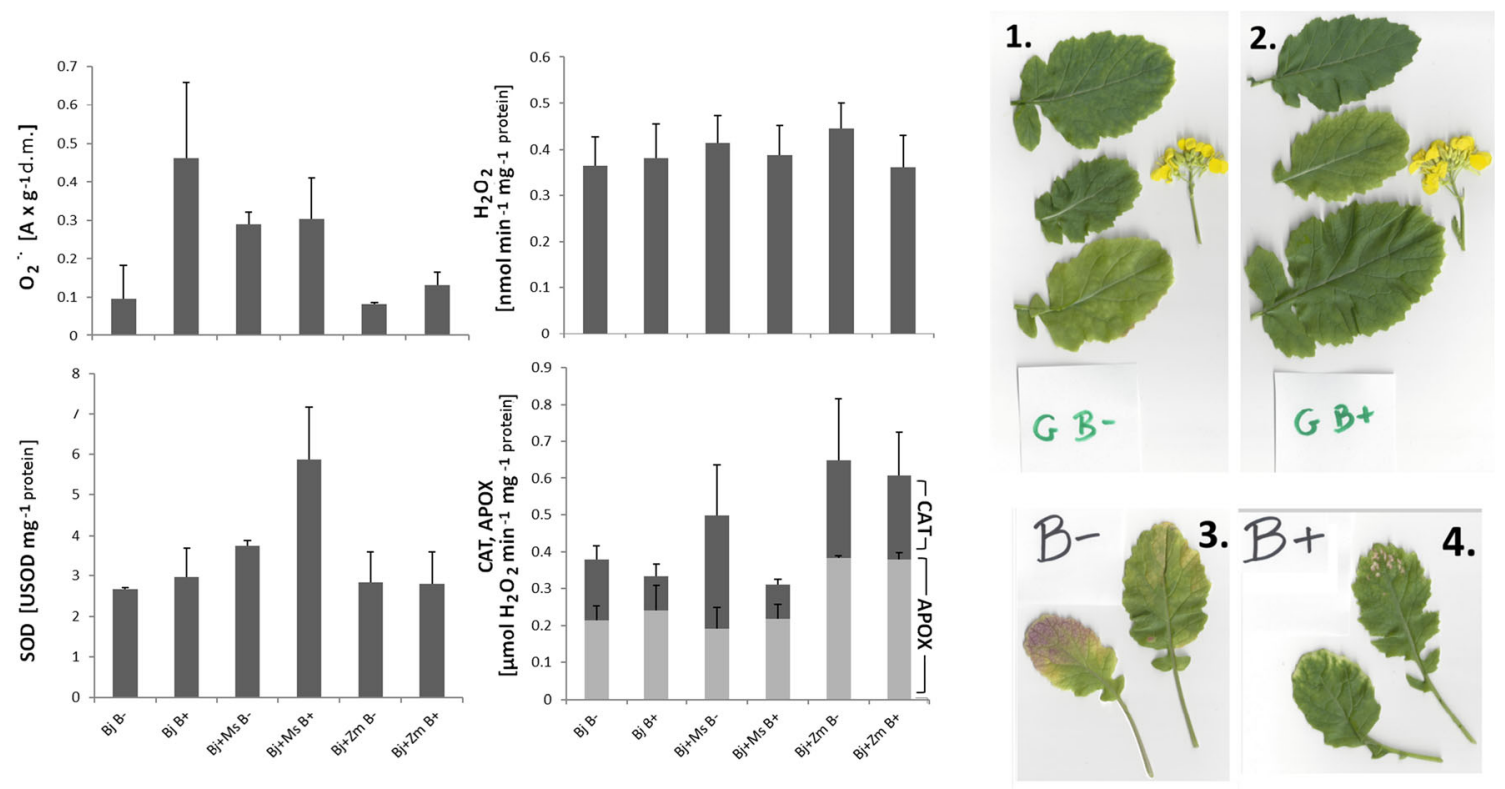

Fig. 3 Left panel: Influence of Burkholderia phytofirmans inoculation and co-planting cultivation on the level of ROS (hydrogen peroxide and superoxide anion) and SOD CAT, APOX activities in B. juncea shoots grown in pots with garden soil and from Piekary Śląskie (MIXTURE 1: 1) in variants: $\mathrm{Bj} \mathrm{B}-, \mathrm{Bj} \mathrm{B}+, \mathrm{Bj}+\mathrm{Ms} \mathrm{B}-, \mathrm{Bj}+\mathrm{Ms} \mathrm{B}+, \mathrm{Bj}+\mathrm{Zm} \mathrm{B}-, \mathrm{Bj}+$ $\mathrm{Zm} \mathrm{B}+. \mathrm{Bj}-$ B. juncea, $\mathrm{Ms}-M$. sativa, $\mathrm{Zm}$ - Z. mays, "B-" - without bacterial inoculation, "B+" - inoculated plants, APOX - ascorbate

inoculation - an increase of $95 \%$ for $\mathrm{Zn}, 90 \%$ for $\mathrm{Cd}$, and approx. $160 \%$ for $\mathrm{Pb}$.

\section{Discussion}

\section{B. juncea-plant useful in the phytoextraction}

In times of increased anthropogenic activity, soil pollution is a serious problem. Several methods are available to remediate soil contaminated with metals, though most of them are expensive and laborious (e.g., excavation of a contaminated material and an off-site treatment). Additionally, soil properties are severely altered after such treatment (Leštan et al. 2008). Phytoextraction is an alternative approach that applies plants for metal removal, either off-site after excavation or on-site. Phytoextraction has become a tangible alternative because it is an environmentally friendly and cost-effective method. There are two strategies for phytoextraction: removal performed by plants with the ability to accumulate high amounts of metals (preferably in the aboveground parts), and removal assisted by plants with a high biomass yield, supplemented with substances to increase the metal uptake (Leštan et al. 2008).

$B$. juncea has been chosen as a primary plant for our research because of its ability to accumulate trace metals, as shown in both lab-scale and field-scale experiments (Rascio and Navari-Izzo 2011; Kutrowska et al. 2017). As peroxidase, CAT - catalase, SOD - superoxide dismutase. Right panel: Influence of Burkholderia phytofirmans inoculation on B. juncea shoot plants. Representative leaves and flowers of $B$. juncea from the control group without inoculation (1) and after PGPR inoculation (2). Most frequently observed changes on the leaves: for control plants - violet coloration (3), for inoculated plants - chlorosis (4). Mean values of three replicates $( \pm \mathrm{SD})$

demonstrated earlier, B. juncea can accumulate $\mathrm{Pb}$ and $\mathrm{Cd}$ (Jiang et al. 2000; Meyers et al. 2008) as well as Cr, Cu, Ni, $\mathrm{Pb}$, and $\mathrm{Zn}$ (Prasad and de Oliveira Freitas 2003; Babula et al. 2012). It belongs to Brassicaceae, a family rich in metallophytes (among others from the Noccaea caerulescens, Brassica, Arabidopsis genera) (Kramer 2010). Literature analysis of experiments involving $B$. juncea shows that this plant is susceptible to the positive influence of microbial inoculation and can be stimulated to increase metal phytoextraction rate. Inoculation with different PGPR can increase metal content in $B$. juncea shoots, e.g., up to twofold for copper (Ma et al. 2009) or up to twofold for lead (Wu et al. 2006).

As complementary plants, we chose Medicago sativa and Zea mays plants; M. sativa is a Fabaceae plant that in the field enters into symbiosis with rhizobia, which can increase the availability of nitrogen for both their host and its accompanying plants (Markmann and Parniske 2009). There are studies describing the use of $M$. sativa for stimulated phytoextraction (e.g., with EDTA) (Lopez et al. 2005), metal rhizofiltration from aqueous solutions (Tiemann et al. 2002), and phytostabilization (Neuman and Schafer 2006). In turn, $Z$. mays is one of the most frequently studied species in terms of phytoextraction-supported chelators, due to its rapid biomass growth and high tolerance to stress (e.g., Komarek et al. 2007; Zhao et al. 2010; Niu et al. 2012). In addition, the $Z$. mays strategy for the uptake of Fe from the environment is 


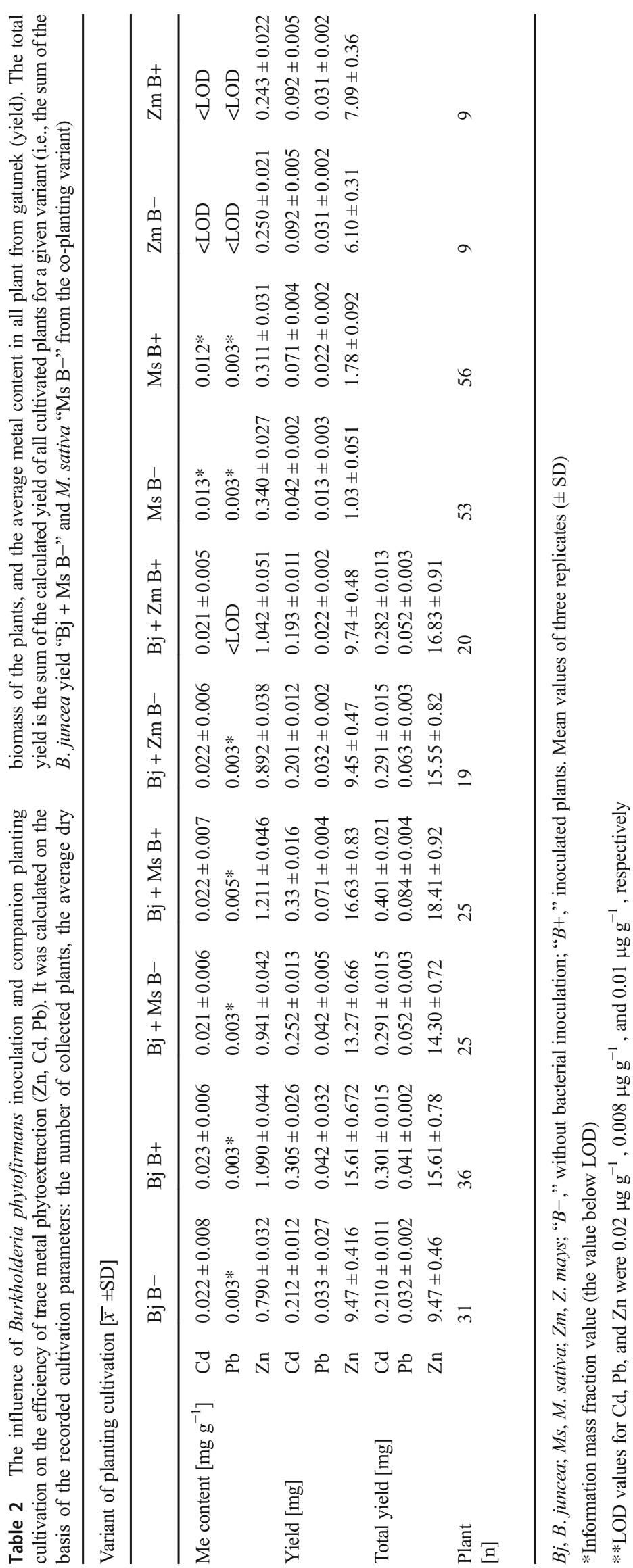


different to that of B. juncea and M. sativa. Namely, Z. mays is able to synthesize phytosiderophores, natural chelators that increase the mobility of metals in soil (Curie et al. 2009; Rajkumar et al. 2010).

\section{Influence of PGPR on plants}

In the presented experiments, we used B. phytofirmans $\mathrm{PsJN}^{\mathrm{T}}$ as an inoculum. It is a strain characterized by high activity of ACC deaminase and ability to produce indolylacetic acid which stimulates root growth (Sessitsch et al. 2005; Weilharter et al. 2011). It is known that the impact of PGPR depends on a number of parameters, including plant genotype, inoculum density, and inoculation method (e.g., inoculum temperature) (Pillay and Nowak 1997). It also depends on the stage of the plant development and a plant's physiological state, because the colonization of plants is associated with the induction of stress (Van Loon 2007). In addition, the effect of a single seed inoculation may also persist at the mature plant stage (Poupin et al. 2013).

Preliminary tests showed a strong inhibition in the growth of the tested plant species (Zea mays, Brassica juncea, and Medicago sativa) on contaminated soil taken from Piekary Śląskie (data not shown). Most likely, contamination with many metals, especially $\mathrm{Pb}$ and $\mathrm{Zn}$, contributed to the observed marked effects on germination and plant growth. It was necessary to supplement the soil from Piekary Śląskie with organic compounds by mixing it with garden soil.

Many studies indicate the significant role of bacteria promoting growth in the extraction and removal of trace elements from contaminated soil, among others by increasing biomass growth, which in turn leads to an increase in the efficiency of metal extraction. Examples of microbial-induced promotion of plant growth and increasing stress resistance in phytoextraction studies can be found in crops, hyperaccumulators, and trees. The effect of increasing tolerance on stress is most often associated with the reaction catalyzed by the enzyme ACC deaminase leading to a reduction of ethylene levels in the plant (Arshad et al. 2007; Glick 2003, 2010).

\section{Effect of PGPR inoculation on the uptake and translocation of metals in plants}

The analysis of metal content (Fig. 1) in the studied plant shoots showed a positive effect of PGPR inoculation on the uptake and translocation of $\mathrm{Cd}, \mathrm{Zn}$, and $\mathrm{Pb}$ in $B$. juncea plants, in comparison with non-inoculated plants. However, the inoculation of PGPR did not have any significant effect on the content of metals in $Z$. mays and $M$. sativa from the co-planted variants with the $B$. juncea. There are studies that show a correlation between higher biomass production with enhanced remediation. Bacteria containing ACC deaminase modulate accelerated production of ethylene in plants treated with metals, and might cause an enhanced uptake of inorganic contaminants through modification of root architecture and also the metal uptake system of the root. Nicotiana tobacco plants inoculated with Pseudomonas putida UW4 showed an increase in both growth and metal accumulation from nickel-contaminated soil (Li et al. 2007). Similarly, Belimov et al. (2005) reported a positive correlation between ACC deaminase activity of the bacteria and enhanced accumulation of cadmium in Brassica juncea tissues through enhanced root growth. The authors suggested that bacteria with ACC deaminase could be used for phytoremediation of metal-contaminated soils. It was found that inoculation with rhizobacterial strains belonging to the genera Burkholderia, in both hydroponically and soil-grown plants of $S$. alfredii, at $\mathrm{Cd} / \mathrm{Zn}$-hyperaccumulator, improved metal tolerance, biomass production, and mostly $\mathrm{Cd}$ uptake and extraction (Li et al. 2007; Guo et al. 2010). Moreover, $\mathrm{Wu}$ et al. (2006) noted a decrease in cadmium phytotoxicity and an increase in $\mathrm{Cd}$ accumulation of up to $40 \%$ in a sunflower plant root inoculated with a strain of Pseudomonas putida 06909.

\section{Defensive antioxidative mechanisms in PGPR inoculated and in co-planting plants}

Trace metals induce the generation of ROS, including the superoxide radical $\left(\mathrm{O}_{2}{ }^{-}\right)$and hydrogen peroxide $\left(\mathrm{H}_{2} \mathrm{O}_{2}\right)$. This can cause cell death due to oxidative stress such as membrane lipid peroxidation, protein oxidation, enzyme inhibition, and damage to nucleic acids. To repair the metalinduced negative effects of ROS, plants employ antioxidant defense mechanisms. Among antioxidative enzymes, superoxide dismutase (SOD; EC, 1.15.1.1) constitutes the primary step of cellular defense and dismutates $\mathrm{O}_{2}{ }^{--}$to $\mathrm{H}_{2} \mathrm{O}_{2}$ and $\mathrm{O}_{2}$. Further, the accumulation of $\mathrm{H}_{2} \mathrm{O}_{2}$ is converted to $\mathrm{H}_{2} \mathrm{O}$ through the action of catalase (CAT; EC, 1.11.1.6) or ascorbate peroxidase (APX; EC, 1.11.1.11). Increased levels of superoxide anions and SOD activity, observed in the vaccinated plants, should result in a dismutation reaction to increased production of hydrogen peroxide. However, in the same plants (Fig. 3), small differences (statistically insignificant) in the level of hydrogen peroxide and a decrease in the level of CAT activity were observed (with the exception of the " $\mathrm{Bj}+\mathrm{Zm} \mathrm{B+"} \mathrm{variant).} \mathrm{This}$ may suggest the participation of other hydrogen peroxide decomposing enzymes (e.g., other peroxidases) in response to stress (Neill et al. 2002; Slesak et al. 2007). Kohler et al. (2009) also observed a decrease in CAT activity (by 55\%) under the influence of PGPR inoculation with Pseudomonas mendocina. A similar decrease in CAT activity was observed by Upadhyay et al. (2012) in wheat inoculated with Bacillus subtilis and Arthrobacter sp. and also by Sandhya et al. (2010) in maize inoculated with 
Pseudomonas sp. cultivated under salt stress conditions. In addition, Kohler et al. (2009) observed increased total peroxidase activity in lettuce under the influence of salt stress and inoculation with arbuscular fungi. The change in plant response to biotic stress (presence of PGPB), not only abiotic (presence of heavy metals), is also confirmed by a reduction in the frequency of the appearance of a violet color of leaves in the inoculated plants (Fig. 2). The violet color is related to the synthesis of phenolic compounds that can limit oxidative stress levels and bind metals (Michalak 2006).

In $B$. juncea plants inoculated with PGPR, compared with non-inoculated plants from the corresponding variants (independent cultivation, co-planting with $M$. sativa), a decrease in the level of synthesis of antioxidant enzymes (CuZnSOD) was also observed (Fig. 4). Interestingly, in the study of Peinado-Guevara et al. (2017) on Solanum lycopersicum grown with arbuscular mycorrhizal fungus (AMF) Rhizophagus irregularis, the authors also noted a decrease in CuZnSOD content after inoculation, with a simultaneous increase in ROS generation. The authors even hypothesized that genotypes displaying an increase in ROS concentration in leaves as a consequence of the decrease in antioxidative enzymes can trigger mycorrhiza-induced defenses. Our results could suggest that a similar mechanism is present after PGPR inoculation.

\section{Influence of PGPR and co-planting on efficiency of trace metals phytoextraction}

Based on the values of the five observed parameters: $\mathrm{Zn}, \mathrm{Cd}$, $\mathrm{Pb}$ content, the number of collected plants (indicating survival), and the average dry biomass of plants, results of metal phytoextraction were collated made (Tab. 2). One of the main factors influencing the efficiency of phytoextraction is the high yield of dry biomass. B. juncea, characterized by a higher biomass production, is considered to be more efficient in $\mathrm{Zn}$ phytoextraction even than $T$. caerulescens, although it accumulates three times less $\mathrm{Zn}$ per kilogram of biomass compared with the hyperaccumulator (Bhargava et al. 2012). Despite the reduced number of plants, the average dry biomass of $B$. juncea from the variant of the " $\mathrm{Bj}+\mathrm{Zm}$ " culture was increased in relation to the plant parameters from the " $\mathrm{Bj}$ " control variant (Fig. 2). It is worth paying attention to a very interesting observation that despite the reduction in the number of B. juncea seeds in the co-planting variants (from 12 to 6 seeds) and limiting the number of plants in the pot (up to 6 or 3 ), relative to the cultivation of $B$. juncea alone, the amount of collected plants (Tab. 2) in co-planting was 50\% higher than in independent variants. It was respectively 80 and $69 \%$ ( $B$. juncea cultivated with $M$. sativa without and after inoculation) and 61 and $56 \%$ (B. juncea cultivated with Z. mays, without and after inoculation), for independent cultivation without and after inoculation. In addition, crops from co-planting variants were characterized by higher average dry biomass and (in some cases) higher metal accumulation. Wu et al. (2006) also noted that PGPB inoculation indirectly translates into a higher efficiency of phytoextraction (higher uptake of metals) by increasing the dry biomass. On the other hand, the positive effect of co-planting cultures on yield is most probably related to, among others, the increase in the bioavailability of microand macroelements (Hauggaard-Nielsen et al. 2001), including trace metals. Thus, it was possible to confirm the hypothesis that the yield of metals from co-planting culture may be similar to that in independent culture, due to the better growth of the plants compared with monoculture (Jiang et al. 2010).

In the co-planting culture of B. juncea and Z. mays, the most important factor increasing the hypothetical efficiency of phytoextraction was the increase in the dry biomass of $Z$. mays. It is known that on soil with low availability of iron, $Z$. mays secretes phytosiderophores (Curie et al. 2009).

However, in the soil used for research, the level of bioavailable iron was high (Table 1), so there was no effect of coplanting on increasing metal uptake.

The influence of plants grown in co-planting cultures is difficult to classify, because it largely depends on the physicochemical properties of the soil. Similarly, Jiang et al. (2010) showed that in the conditions of hydroponic cultivation of $Z$. mays, independently and co-planted with the hyperaccumulator
Fig. 4 Superoxide dismutase isoforms level (CuZnSOD and FeSOD) in B. juncea plants grown in monoculture $(\mathrm{Bj})$, with Zea mays $(\mathrm{Bj}+\mathrm{Zm})$ or with Medicago sativa $(\mathrm{Bj}+\mathrm{Ms})$, without (B-) or after Burkholderia phytofirmans inoculation $(\mathrm{B}+)$, detected using Western blot. $\mathrm{Bj}-$ B. juncea, $\mathrm{Ms}$ M. sativa, $\mathrm{Zm}-\mathrm{Z}$. mays, "B-" without bacterial inoculation, "B+ " - inoculated plants. Mean values of three replicates $( \pm \mathrm{SD})$
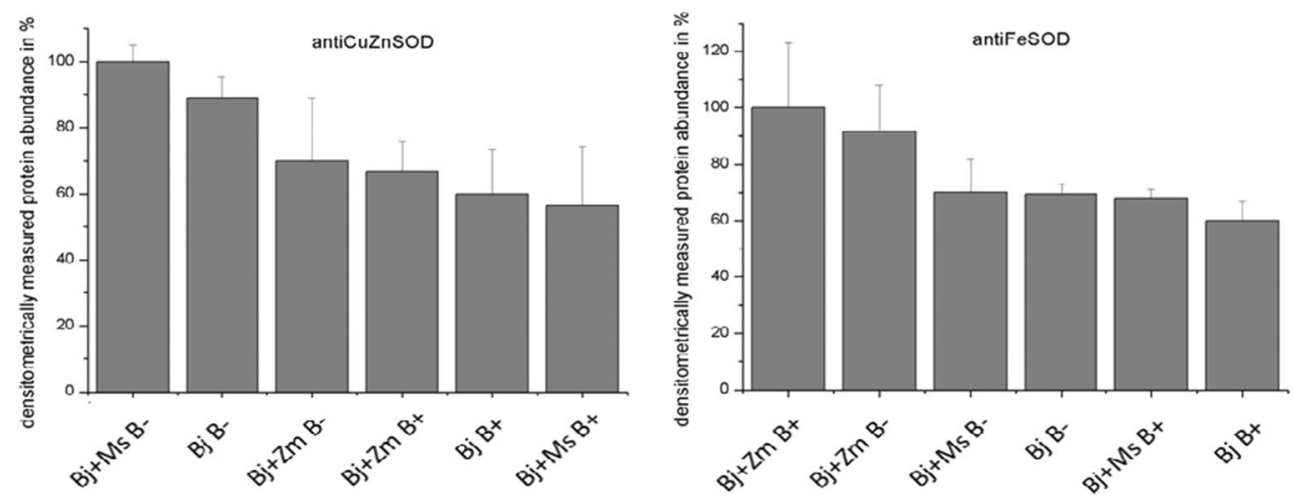
Sedum alfredii species, the factor modulating the uptake of metals was $S$. alfredii exudates, not $Z$. mays exudates. In the co-planting culture of $B$. juncea with $M$. sativa, the most significant impact on the hypothetical efficiency of phytoextraction was both the increase of metals in plants and the increase in the dry biomass. In a mesocosm experiment in which tobacco and clover were grown alongside, Liu et al. (2011) showed the relationship between co-planting and $\mathrm{pH}$ reduction that increased $\mathrm{Cd}$ mobility and BCFCd. Because the clover is closely related to $M$. sativa, it is possible that the results of the experiment presented in the current paper-an elevated level of metals in $B$. juncea plants cultivated with $M$. sativa (Fig.1) — could be explained partially by lowering the $\mathrm{pH}$ of $M$. sativa, resulting in increased availability of metals.

The presence of PGPR contributed to an increase in the dry biomass of $Z$. mays and $M$. sativa plants, relative to noninoculated plants for each variant of the culture with $B$. juncea (Fig. 2). An increasing level of dry biomass is a frequent effect of PGPR inoculation. As shown by Upadhyay et al. (2012), wheat inoculation increases the level of dry biomass, total soluble sugar, and proline content. Similarly, Wu et al. (2006) observed that inoculation of B. juncea with PGPR (Azotobacter chroococcum, Bacillus megaterium, Bacillus mucilaginosus) protects plants from the effects of heavy metals and results in an increase in the dry biomass of plants. Sandhya et al. (2010) also observed that in PGPR-inoculated plants there is an increase in biomass, relative water content, leaf water potential, and mean stem diameter and a higher level of proline, sugars, and free amino acids. In the case of B. juncea plants, the increase in the harvest of dry biomass was influenced both by the cultivation of co-planting and the PGPR inoculation. Here, as in the case of the analyzed level of ROS and enzyme activity, the only exception to this profile were the $B$. juncea plants co-planted with the $Z$. mays after inoculation (relative to non-inoculated plants). In this variant, a reduced level of average dry biomass and a different chlorophyll $a$ and $b$ profile were observed (Fig. 2). This indicates additional interactions between these three organisms, but the explanation of this mechanism requires further research. Interestingly, Z. mays plants from this variant were characterized by increased average dry biomass, shoot length, and fresh biomass (Fig. 2). Jiang et al. (2008) studied the effect of Burkholderia on individual cultures of maize, Indian mustard, and tomato on soil contaminated with heavy metals: $\mathrm{Pb}\left(150.1 \mathrm{mg} \mathrm{kg}^{-1}\right.$ of soil) and $\mathrm{Cd}$ (37.3 $\mathrm{mg} \mathrm{kg}^{-1}$ of soil). The results indicated that inoculation resulted in an increase in the dry mass of $Z$. mays roots and shoots (by $75 \%$ and $30 \%$, respectively) and $\mathrm{Cd}$ and $\mathrm{Pb}$ uptake, whereas in B. juncea, no significant increase was observed (except for the increased of $\mathrm{Cd}$ uptake in $B$. juncea roots). This may indicate the existence of a potentially lower positive effect of inoculation with Burkholderia on B. juncea compared with $Z$. mays plants. In our study, it was found that neither coplanting culture nor bacterial inoculation separately had any effect on the photosynthetic apparatus of $B$. juncea leaves, whereas their combined effect led to a significant decrease in the content of photosynthetic pigments (chlorophylls $a$ and $b$ ) only in variants $\mathrm{Bj}+\mathrm{Ms} \mathrm{B}+$. The effect of heavy metals on photosynthesis is quite widely reported in the scientific literature (Tran and Popova 2013; Muratova et al. 2015; Sitko et al. 2017). It is known that cadmium destroys the structure and function of chloroplasts, as well as reduces the content and ratio of photosynthetic pigments as a consequence of inhibition of the biosynthesis and degradation of chlorophyll (Muratova et al. 2015). It is not known what effect probiotic bacteria have on the photosynthetic apparatus. There are works that report that inoculation of stressed plants with plant growthpromoting microorganisms, e.g., Rhizobium sp., Bacillus subtilis, and Pseudomonas fluorescens, resulted in an increase in chlorophyll and carotenoid content (Wani and Khan 2013; Muratova et al. 2015). In the variant containing B. juncea with M. sativa and PGPR, it is possible that the bacterial inoculum increased heavy metal uptake, which was followed by an increase in the toxic effect of the metal on the photosynthetic apparatus. This explanation may be supported by the data demonstrating an enhancement of heavy metal accumulation by variant $\mathrm{Bj}+\mathrm{Ms} \mathrm{B}+$.

\section{Conclusions}

Our results show that the combined effect of co-planting and PGPR inoculation can increase the efficiency of phytoextraction. Optimization of the culture parameters: inoculation density, selection of accompanying plant species, PGPR strains, has the power to increase dry biomass yield and survivability and modulate the stress response and stress propagation in plants. The obtained results indicate that coplanting and PGPR inoculation have a positive effect on the phytoextraction process. We have shown an increase in the quantity and biomass of $B$. juncea in co-planting by over $50 \%$ compared with monoculture. Therefore, the use of coplanting in induced phytoextraction is of great significance for application.

Thus, the phytoextraction efficiency of these plants in large-scale crops and in the presence of PGPR bacteria should be checked. What is important from our point of view is the fact of monitoring soil microorganisms and their activity in assessing the effectiveness of the applied remediation method.

\section{Outlooks}

The phytoextraction efficiency of these plants in large-scale crops and in the presence of PGPR bacteria should be checked. At the same time, the development of various bacterial consortia that would increase the accumulation of heavy 
metals in different soil conditions and for different plants would be of great practical importance.

Acknowledgments The authors would like to thank Professor Angela Sessitsch from the Austrian Institute of Technology for sharing the

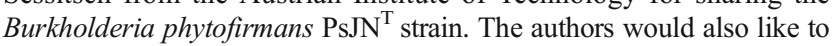
thank Dominika Nowak, MSc, and Ewa Santracz, MSc, for their involvement in the realization of the project and Elżbieta Małkowska, MSc, and Łukasz Małkowski, MSc, for their help with the selection and collection of contaminated soil.

Funding information This research was partially supported by the National Science Center in Poland (project numbers N N305 381138 and 2013/11/N/NZ9/00070). KA is also a beneficiary of the program "KNOW Poznan RNA Centre, 01/KNOW2/2014." AH was supported by a grant of the National Science Center in Poland no. 2017/01/X/ST4/ 00373.

\section{Compliance with ethical standards}

Conflict of interest The authors declare that they have no conflict of interest.

Disclaimer The funding sponsors had no role in the design of the study; in the collection, analyses, or interpretation of data; in the writing of the manuscript; and in the decision to publish the results.

Open Access This article is licensed under a Creative Commons Attribution 4.0 International License, which permits use, sharing, adaptation, distribution and reproduction in any medium or format, as long as you give appropriate credit to the original author(s) and the source, provide a link to the Creative Commons licence, and indicate if changes were made. The images or other third party material in this article are included in the article's Creative Commons licence, unless indicated otherwise in a credit line to the material. If material is not included in the article's Creative Commons licence and your intended use is not permitted by statutory regulation or exceeds the permitted use, you will need to obtain permission directly from the copyright holder. To view a copy of this licence, visit http://creativecommons.org/licenses/by/4.0/.

\section{References}

Aebi HE (1983) In: HU BERGMEYER (ed) Catalase. Methods of enzymatic analysis, vol III. Verlag Chemie, Weinheim, pp 273-282

Aelion CM, Davis HT (2007) Use of a general toxicity test to predict heavy metal concentrations in residential soils. Chemosphere 67(5): 1043-1049. https://doi.org/10.1016/j.chemosphere.2006.10.042

Ali H, Khan E, Sajad MA (2013) Phytoremediation of heavy metalsconcepts and applications. Chemosphere 91(7):869-881. https://doi. org/10.1016/j.chemosphere.2013.01.075

Andersen E, Peiter E, Küpper H (2018) Trace metal metabolism in plants. J Exp Bot 69(5):909-954. https://doi.org/10.1093/jxb/erx465

Arshad M, Saleem M, Hussain S (2007) Perspectives of bacterial ACC deaminase in phytoremediation. Trends Biotechnol 25(8):356-362

Babula P, Adam V, Havel L, Kizek R (2012) Cadmium accumulation by plants of Brassicaceae family and its connection with their primary and secondary metabolism. In: The plant family Brassicaceae. Springer, Netherlands, pp 71-97. https://doi.org/10.1007/978-94007-3913-0 3
Beauchamp C, Fridovich I (1971) Superoxide dismutase: improved assays and an assay applicable to acrylamide gels. Anal Biochem 44(1):276-287

Belimov AA, Hontzeas N, Safronova VI, Demchinskaya SV, Piluzza G, Bullitta S, Glick BR (2005) Cadmium-tolerant plant growthpromoting bacteria associated with the roots of Indian mustard (Brassica juncea L. Czern.). Soil Biol Biochem 37(2):241-250

Bhargava A, Carmona FF, Bhargava M, Srivastava S (2012) Approaches for enhanced phytoextraction of heavy metals. J Environ Manag 105:103-120. https://doi.org/10.1016/j.jenvman.2012.04.002

Bhattacharyya PN, Jha DK (2012) Plant growth-promoting rhizobacteria (PGPR): emergence in agriculture. World J Microbiol Biotech 28(4):1327-1350. https://doi.org/10.1007/s11274-011-0979-9

Bradford MM (1976) A rapid and sensitive method for the quantitation of microgram quantities of protein utilizing the principle of protein-dye binding. Anal Biochem 72(1-2):248-254

Chiang PN, Wang MK, Chiu CY, Chou SY (2006) Effects of cadmium amendments on low-molecular-weight organic acid exudates in rhizosphere soils of tobacco and sunflower. Environ Toxicol 21(5): 479-488

Compant S, Kaplan H, Sessitsch A, Nowak J, Barka E A, Clément C (2008) Endophytic colonization of Vitis vinifera L. by Burkholderia phytofirmans strain PsJN: from the rhizosphere to inflorescence tissues. FEMS Microbiol Ecol 63(1):84-93. https://doi.org/10.1111/j. 1574-6941.2007.00410.x

Curie C, Cassin G, Couch D, Divol F, Higuchi K, Le Jean M, Misson J, Schikora A, Czernic P, Mari S (2009) Metal movement within the plant: contribution of nicotianamine and yellow stripe 1-like transporters. Ann Bot 103:1-11. https://doi.org/10.1093/aob/mcn207

Doke N (1983) Involvement of superoxide anion generation in the hypersensitive response of potato tuber tissues to infection with an incompatible race of Phytophthora infestans and to the hyphal wall components. Physiol Plant Pathol 23(3):345-357. https://doi.org/10. 1016/0048-4059(83)90019-X

Douay F, Pelfrêne A, Planque J, Fourrier H, Richard A, Roussel H, Girondelot B (2013) Assessment of potential health risk for inhabitants living near a former lead smelter. Part 1: metal concentrations in soils, agricultural crops, and homegrown vegetables. Environ Monit Assess 185(5):3665-3680. https://doi.org/10.1007/s10661012-2818-3

Duarte B, Delgado M, Cacador I (2007) The role of citric acid in cadmium and nickel uptake and translocation, in Halimione portulacoides. Chemosphere 69(5):836-840

Etesami H (2018) Bacterial mediated alleviation of heavy metal stress and decreased accumulation of metals in plant tissues: mechanisms and future prospects. Ecotoxicol Environ Saf 147:175-191. https://doi. org/10.1016/j.ecoenv.2017.08.032

Evangelou MWH, Ebel M, Schaeffer A (2006) Evaluation of the effect of small organic acids on phytoextraction of $\mathrm{Cu}$ and $\mathrm{Pb}$ from soil with tobacco Nicotiana tabacum. Chemosphere 63(6):996-1004

Glick BR (2003) Phytoremediation: synergistic use of plants and bacteria to clean up the environment. Biotechnol Adv 21(5):383-393

Glick BR (2010) Using soil bacteria to facilitate phytoremediation. Biotechnol Adv 28:367-374. https://doi.org/10.1016/j.biotechadv. 2010.02.001

Goswami D, Thakker JN, Dhandhukia PC (2016) Portraying mechanics of plant growth promoting rhizobacteria (PGPR): a review. Cogent Food Agric 2:1127500. https://doi.org/10.1080/23311932.2015. 1127500

Guo HJ, Luo SL, Chen L, Xiao X, Xi Q, Wei WZ, Zeng G, Liu C, Wan Y, Chen J, He Y (2010) Bioremediation of heavy metals by growing hyperaccumulator endophytic bacterium Bacillus sp. L14. Bioresour Technol 101:8599-6605

Hanć A, Małecka A, Kutrowska A, Bagniewska-Zadworna A, Tomaszewska B, Barałkiewicz D (2016) Direct analysis of elemental biodistribution in pea seedlings by LA-ICP-MS, EDX and 
confocal microscopy: imaging and quantification. Microchem J 128: 305-311. https://doi.org/10.1016/j.microc.2016.05.008

Hauggaard-Nielsen H, Ambus P, Jensen ES (2001) Interspecific competition, $\mathrm{N}$ use and interference with weeds in pea-barley intercropping. Field Crops Res 70(2):101-109

He LY, Chen ZJ, Ren GD, Zhang YF, Qian M, Sheng XF (2009) Increased cadmium and lead uptake of a cadmium hyperaccumulator tomato by cadmium-resistant bacteria. Ecotoxicol Environ Saf 72(5):1343-1348

He HD, Ye ZH, Yang DJ, Yan JL, Xiao L, Zhong T et al (2013) Characterization of endophytic Rahnella sp. JN6 from Polygonum pubescens and its potential in promoting growth and $\mathrm{Cd}, \mathrm{Pb}, \mathrm{Zn}$ uptake by Brassica napus. Chemosphere 90:1960-1965. https:// doi.org/10.1016/j.chemosphere.2012.10.057

Held DW, Gonsiska P, Potter DA (2003) Evaluating companion planting and non-host masking odors for protecting roses from the Japanese beetle (Coleoptera: Scarabaeidae). J Econ Entomol 96(1):81-87. https://doi.org/10.1093/jee/96.1.81Jiang

Jadia C, Fulekar M (2009) Phytoremediation of heavy metals: recent techniques. African J Biotech 8:921-928

Jiang CY, Sheng XF, Qian M, Wang QY (2008) Isolation and characterization of a heavy metal-resistant Burkholderia $s p$. from heavy metal-contaminated paddy field soil and its potential in promoting plant growth and heavy metal accumulation in metal-polluted soil. Chemosphere 72(2):157-164. https://doi.org/10.1016/j. chemosphere.2008.02.006

Jiang W, Liu D, Hou W (2000) Hyperaccumulation of lead by roots, hypocotyls, and shoots of Brassica juncea. Biol Plant 43:603-606. https://doi.org/10.1023/A:1002804100215

Jiang C, Wu QT, Sterckeman T, Schwartz C, Ouvrard S, Perriguey J, Morel JL (2010) Co-planting can phytoextract similar amounts of cadmium and zinc to mono-cropping from contaminated soils. Ecol Eng 36(4):391-395

Karami A, Shamsuddin Z (2010) Phytoremediation of heavy metals with several efficiency enhancer methods. Afr J Biotech 9(25):36893698

Khan AG (2005) Role of soil microbes in the rhizosphere of plants growing on trace metal contaminated soils in phytoremediation. J Trace Elem Med Biol 18:355-364

Kohler J, Hernández JA, Caravaca F, Roldán A (2009) Induction of antioxidant enzymes is involved in the greater effectiveness of a PGPR versus AM fungi with respect to increasing the tolerance of lettuce to severe salt stress. Environ Exp Bot 65(2):245-252

Komarek M, Tlustos P, Szakova J, Chrastny V, Ettler V (2007) The use of maize and poplar in chelant-enhanced phytoextraction of lead from contaminated agricultural soils. Chemosphere 67(4):640-651. https://doi.org/10.1016/j.chemosphere.2006.11.010

Kramer U (2010) Metal hyperaccumulation in plants. Annu Rev Plant Biol 61:517-534

Kucharski R, Sas-Nowosielska A, Małkowski E, Japenga J, Kuperberg JM, Pogrzeba M, Krzyżak J (2005) The use of indigenous plant species and calcium phosphate for the stabilization of highly metal-polluted sites in southern Poland. Plant Soil 273(1-2):291305

Kutrowska A, Małecka A, Piechalak A, Masiakowski W, Hanć A, Barałkiewicz D, Tomaszewska B (2017) Effects of binary metal combinations on zinc, copper, cadmium and lead uptake and distribution in Brassica juncea. J Trace Elem Med Biol 44:32-39. https:// doi.org/10.1016/j.jtemb.2017.05.007

Leštan D, Luo CL, Li XD (2008) The use of chelating agents in the remediation of metal-contaminated soils: a review. Environ Poll 153(1):3-13. https://doi.org/10.1016/j.envpol.2007.11.015

Li WC, Ye ZH, Wong MH (2007) Effects of bacteria on enhanced metal uptake of the $\mathrm{Cd} / \mathrm{Zn}$ hyperaccumulating plant, Sedum alfredii. J Exp Bot 58:4173-4182
Liu L, Li Y, Tang J, Hu L, Chen X (2011) Plant coexistence can enhance phytoextraction of cadmium by tobacco (Nicotiana tabacum L.) in contaminated soil. J Environ Sci 23(3):453-460. https://doi.org/10. 1016/S1001-0742(10)60430-5

Lopez ML, Peralta-Videa JR, Benitez T, Gardea-Torresdey JL (2005) Enhancement of lead uptake by alfalfa (Medicago sativa) using EDTA and a plant growth promoter. Chemosphere 61(4):595-598. https://doi.org/10.1016/j.chemosphere.2005.02.028

Ma Y, Rajkumar M, Freitas H (2009) Inoculation of plant growth promoting bacterium Achromobacter xylosoxidans strain Ax10 for the improvement of copper phytoextraction by Brassica juncea. $\mathrm{J}$ Environ Manag 90(2):831-837. https://doi.org/10.1016/j.jenvman. 2008.01.014

Ma Y, Rajkumar M, Rocha I, Oliveira RS, Freitas H (2015) Serpentine bacteria influence metal translocation and bioconcentration of Brassica juncea and Ricinus communis grown in multi-metal polluted soils. Front Plant Sci 5:757

Ma Y, Rajkumar M, Zhang C, Freitas H (2016) Beneficial role of bacterial endophytes in heavy metal phytoremediation. J Environ Manag 174: 14-25. https://doi.org/10.1016/j.jenvman.2016.02.047

Markmann K, Parniske M (2009) Evolution of root endosymbiosis with bacteria: how novel are nodules? Trends Plant Sci 14(2):77-86. https://doi.org/10.1016/j.tplants.2008.11.009

Marques A, Rangel A, Castro PML (2009) Remediation of heavy metal contaminated soils: phytoremediation as a potentially promising clean-up technology. Crit Rev Environ Sci Technol 39(8):622-654

McGrath SP, Zhao FJ (2003) Phytoextraction of metals and metalloids from contaminated soils. Curr Opin Biotechnol 14(3):277-282

Mead R, Willey RW (1980) The concept of a 'land equivalent ratio' and advantages in yields from intercropping. Exp Agric 16(03):217228. https://doi.org/10.1017/S0014479700010978

Meyers DE, Auchterlonie GJ, Webb RI, Wood B (2008) Uptake and localization of lead in the root system of Brassica juncea. Environ Pollut 153:323-332. https://doi.org/10.1016/j.envpol.2007.08.029

Michalak A (2006) Phenolic compounds and their antioxidant activity in plants growing under heavy metal stress. Pol J Environ Stud 15(4): $523-530$

Muratova A, Lyubun Y, German K, Turkovskaya O (2015) Effect of cadmium stress and inoculation with a heavy-metal-resistant bacterium on the growth and enzyme activity of Sorghum bicolour. Environ Sci Pollut Res 22:16098-16109

Nakano Y, Asada K (1981) Hydrogen peroxide is scavenged by ascorbate-specific peroxidase in spinach chloroplasts. Plant Cell Physiol 22(5):867-880. https://doi.org/10.1093/oxfordjournals.pcp. a076232

Neill SJ, Desikan R, Clarke A, Hurst RD, Hancock JT (2002) Hydrogen peroxide and nitric oxide as signalling molecules in plants. J Exp Bot 53(372):1237-1247. https://doi.org/10.1093/jexbot/53.372. 1237

Neugschwandtner RW, Tlustos P, Komarek M, Szakova J (2008) Phytoextraction of $\mathrm{Pb}$ and $\mathrm{Cd}$ from a contaminated agricultural soil using different EDTA application regimes: laboratory versus field scale measures of efficiency. Geoderma 144:446-453

Neuman DR, Schafer WM (2006) Phytostabilization of fluvial tailings deposits in the Clark Fork river floodplain. In Proc. Int. Conf. Acid Rock Drainage, 7th, St. Louis, pp 26-30

Niu L, Shen Z, Luo C, Deng Y, Wang C (2012) Accumulation mechanisms and subcellular distribution of $\mathrm{Cu}$ in maize grown on soil treated with [S, S]-ethylenediamine disuccinic acid. Plant Soil 351(1-2):237-247. https://doi.org/10.1007/s11104-011-0954-0

Olowe VIO, Adeyemo AY (2009) Enhanced crop productivity and compatibility through intercropping of sesame and sunflower varieties. Ann Appl Biol 155(2):285-291

Patterson BD, MacRae EA, Ferguson IB (1984) Estimation of hydrogen peroxide in plant extracts using titanium (IV). Anal Biochem 139(2):487-492 
Peinado-Guevara LI, López-Meyer M, López-Valenzuela JA, Maldonado-Mendoza IE, Galindo-Flores H, Campista-León S, Medina-Godoy S (2017) Comparative proteomic analysis of leaf tissue from tomato plants colonized with Rhizophagus irregularis. Symbiosis 73(2):93-10. https://doi.org/10.1007/s13199-016-04703

Penrose DM, Glick BR (2003) Methods for isolating and characterizing ACC deaminase-containing plant growth promoting rhizobacteria. Physiol Plant 118:10-15. https://doi.org/10.1034/j.1399-3054.2003. 00086.x

Pillay VK, Nowak J (1997) Inoculum density, temperature, and genotype effects on in vitro growth promotion and epiphytic and endophytic colonization of tomato (Lycopersicon esculentum L.) seedlings inoculated with a pseudomonad bacterium. Can J Microbiol 43(4): 354-361. https://doi.org/10.1139/m97-049

Poupin MJ, Timmermann T, Vega A, Zuñiga A, González B (2013) Effects of the plant growth promoting bacterium Burkholderia phytofirmans PsJN throughout the life cycle of Arabidopsis thaliana. PLoS One 8(7):e6943. https://doi.org/10.1371/journal. pone.0069435

Prasad VMN, de Oliveira Freitas HM (2003) Metal hyperaccumulation in plants: biodiversity prospecting for phytoremediation technology. Electron J Biotech 6:285-321. https://doi.org/10.2225/vol6-issue3fulltext-6

Rajkumar M, Ae N, Prasad MNV, Freitas H (2010) Potential of siderophore-producing bacteria for improving heavy metal phytoextraction. Trends Biotechnol 28(3):142-149. https://doi.org/ 10.1016/j.tibtech.2009.12.002

Rajkumar M, Prasad MNV, Sandhya S, Freitas H (2013) Climate change driven plant-metal-microbe interactions. Environ Int 53:74e86

Rascio N, Navari-Izzo F (2011) Heavy metal hyperaccumulating plants: how and why do they do it? And what makes them so interesting? Plant Sci 180:169-181. https://doi.org/10.1016/j.plantsci.2010.08. 016

Robinson BH, Anderson CWN, Dickinson NM (2015) Phytoextraction: where's the action? J Geochem Explor 151:34 40. https://doi.org/ 10.1016/j.gexplo.2015.01.001

Ronen R, Galun M (1984) Pigment extraction from lichens with dimethyl sulfoxide (DMSO) and estimation of chlorophyll degradation. Environ Exp Bot 24(3):239-245. https://doi.org/10.1016/00988472(84)90004-2

Saleem M, Arshad M, Hussain S, Bhatti AS (2007) Perspective of plant growth promoting rhizobacteria (PGPR) containing ACC deaminase in stress agriculture. J Ind Microbiol Biotechnol 34(10):635648. https://doi.org/10.1007/s10295-007-0240-6

Sandhya V, Ali SZ, Grover M, Reddy G, Venkateswarlu B (2010) Effect of plant growth promoting Pseudomonas spp. on compatible solutes, antioxidant status and plant growth of maize under drought stress. Plant Growth Regul 62(1):21-30. https://doi.org/10.1007/ s00203-010-0613-5

Sarma H (2011) Metal hyperaccumulation in plants: a review focusing on phytoremediation technology. J Environ Sci Technol 4(2):118-138. https://doi.org/10.3923/jest.2011.118.138

Sessitsch A, Coenye T, Sturz A V, Vandamme P, Barka E A, Salles J F, Van Elsas J D, Faure D, Reiter B, Glick B R, Pruski G, Nowak J (2005) Burkholderia phytofirmans sp. nov., a novel plant-associated bacterium with plant-beneficial properties. Inter J System Evol Microbiol 55:1187-1192. https://doi.org/10.1099/ijs.0.63149-0

Sessitsch A, Kuffner M, Kidd P, Vangronsveld J, Wenzel WW, Fallmann K, Puschenreiter M (2013) The role of plant-associated bacteria in the mobilization and phytoextraction of trace elements in contaminated soils. Soil Biol Biochem 60:182-194

Sitko K, Rusionowski S, Kalaji HM, Szopiński M, Małkowski E (2017) Photosynthetic efficiency as bioindicator of environmental pressure in A. halleri. Plant Physiol 175:290-302
Slesak I, Libik M, Karpinska B, Karpinski S, Miszalski Z (2007) The role of hydrogen peroxide in regulation of plant metabolism and cellular signalling in response to environmental stresses. Acta Biochim Pol 54(1):39-50

Sobariu DL, Fertu DIT, Diaconu M, Pavel LV, Hlihor RM, Drăgoi EN, Curteanu S, Lenz M, Corvini PF, Gavrilescu M (2017) Rhizobacteria and plant symbiosis in heavy metal uptake and its implications for soil bioremediation. New Biotechnol 39:125-134. https://doi.org/10.1016/j.nbt.2016.09.002

Srivastava S, Singh N (2014) Mitigation approach of arsenic toxicity in chickpea grown in arsenic amended soil with arsenic tolerant plant growth promoting Acinetobacter sp. Ecol Eng 70:146-153. https:// doi.org/10.1016/j.ecoleng.2014.05.008

Stuczyński T, Pistelok F, Siebielec G, Kukla H, Daniels W, Chaney R, Pantuck K (2000) Biological aspects of metal waste reclamation with sewage sludge in Poland. In Proceedings of the symposium on mining, forest and land restoration: the successful use of residuals/biosolids/organic matter for reclamation activities, Denver, July $17-20$

Temperton VM, Mwangi PN, Scherer-Lorenzen M, Schmid B, \& Buchmann N (2007) Positive interactions between nitrogen-fixing legumes and four different neighbouring species in a biodiversity experiment. Oecologia 151(2):190-205

Tiemann KJ, Gamez G, Dokken K, Parsons JG, Gardea-Torresdey JL (2002) Chemical modification and X-ray absorption studies for lead(II) binding by Medicago sativa (alfalfa) biomass. Microchem J71(2-3):287-293

Tran TA, Popova LP (2013) Functions and toxicity of cadmium in plants: recent advances and future prospects. Turk J Bot 37:1-13

Upadhyay SK, Singh JS, Saxena AK, Singh DP (2012) Impact of PGPR inoculation on growth and antioxidant status of wheat under saline conditions. Plant Biol 14(4):605-611. https://doi.org/10.1111/j. 1438-8677.2011.00533.x

Vamerali T, Bandiera M, Mosca G (2010) Field crops for phytoremediation of metal-contaminated land. A review. Environ Chem Lett 8:1-17. https://doi.org/10.1007/s10311-009-0268-0

Van Loon LC (2007) Plant responses to plant growth-promoting rhizobacteria. Eur J Plant Pathol 119(3):243-254. https://doi.org/ 10.1007/s10658-007-9165-1

Verbruggen N, Hermans C, Schat H (2009) Molecular mechanisms of metal hyperaccumulation in plants. New Phytol 181(4):759-757. https://doi.org/10.1111/j.1469-8137.2008.02748.x

Verbruggen N, Juraniec M, Baliardini C, Meyer CL (2013) Tolerance to cadmium in plants: the special case of hyperaccumulators. Biometals 26(4):633-638. https://doi.org/10.1007/s10534-0139659-6

Wang Q, Li Y, Alva A (2010) Cropping systems to improve carbon sequestration for mitigation of climate change. J Environ Prot 1: 207-215

Wani PA, Khan MS (2013) Nickel detoxification and plant growth promotion by multi metal resistant plant growth promoting Rhizobium species RL9. Bull Environ Contam Toxicol 91:117-124

Weilharter A, Mitter B, Shin MV, Chain PSG, Nowak J, Sessitsch A (2011) Complete genome sequence of the plant growth promoting endophyte Burkholderia phytofirmans strain PsJNT. J Bacteriol 193(13):3383-3384. https://doi.org/10.1128/JB.05055-11

Weyens N, van der Lelie D, Taghavi S, Vangronsveld J (2009) Phytoremediation: plant-endophyte partnerships take the challenge. Curr Opin Biotechnol 20(2):248-254. https://doi.org/10.1016/j. copbio.2009.02.012

Wood JL, Tang C, Franks AE (2016) Microbial associated plant growth and heavy metal accumulation to improve phytoextraction of contaminated soils. Soil Biol Biochem 103:131-137

Wu CH, Wood TK, Mulchandani A, Chen W (2006) Engineering plantmicrobe symbiosis for rhizoremediation of heavy metals. Appl Environ Microbiol 72(2):1129-1134 
Wu QT, Wei ZB, Ouyang Y (2007) Phytoextraction of metalcontaminated soil by Sedum alfredii $\mathrm{H}$ : effects of chelator and coplanting. Water Air Soil Poll 180(1-4):131-139. https://doi.org/ 10.1080/10643389.2011.574105

Yang J, Kloepper JW, Ryu C-M (2009) Rhizosphere bacteria help plants tolerate abiotic stress. Trends Plant Sci 14:1-4

Yang R, Liu L, Zan S, Tang J, Chen X (2012) Plants species coexistence alleviates the impacts of lead on Zea mays L. J Environ Sci 24(3): 396-401. https://doi.org/10.1016/S1001-0742(11)60721-3
Zhao Z, Xi M, Jiang G, Liu X, Bai Z, Huang Y (2010) Effects of IDSA, EDDS and EDTA on heavy metals accumulation in hydroponically grown maize (Zea mays, L.). J Hazard Mater 181(1-3):455-459. https://doi.org/10.1016/j.jhazmat.2010.05.032

Publisher's note Springer Nature remains neutral with regard to jurisdictional claims in published maps and institutional affiliations. 